\title{
Hydroclimatological and Paleohydrological Context of Extreme Winter Flooding in Arizona, 1993
}

\author{
by \\ P. Kyle House and Katherine K. Hirschboeck \\ Arizona Geological Survey \\ Open-File Report 95-12
}

October 1995

\author{
Arizona Geological Survey \\ 416 W. Congress, Suite \#100, Tucson, Arizona 85701 \\ P. Kyle House \\ Arizona Laboratory for Paleohydrological and \\ Hydroclimatological Analysis (ALPHA) \\ Department of Geosciences University of Arizona \\ Tucson, Arizona 85721 \\ Katherine K. Hirschboeck \\ Laboratory of Tree-Ring Research \\ and Arizona Laboratory for Paleohydrological and \\ Hydroclimatological Analysis (ALPHA) \\ Department of Geosciences University of Arizona \\ Tucson, Arizona 85721
}





\section{ABSTRACT}

Extreme flooding in Arizona during the winter of 1993 resulted from a nearly optimal combination of flood-enhancing factors involving hydroclimatology, hydrometeorology and physiography. The flooding which occurred throughout January and February resulted from record precipitation due to a high frequency of winter frontal passages. These fronts were steered across the state by an exceptionally active storm track, located unusually far south. The number of individual storms that entered the region and the relative position of each storm track in relation to previous storms was reflected in a complex spatial and temporal distribution of flood peaks. An analysis of the hydroclimatic context of these floods supports a general conclusion that in Arizona, front-generated winter precipitation is the cause of the most extreme floods in large watersheds, even in basins that tend to experience their greatest frequency of flooding from other types of storms. A comparison of the 1993 floods with gaged, historical, and paleoflood data from Arizona indicates that although many individual flood peaks were quite large, they were within the range of documented extreme flooding over the past 1000+ years. The 1993 flood scenario provides a convincing analogue for the climatic and hydrologic processes that must have operated to generate comparably large paleofloods, i.e., abnormally high rainfall totals, repeated accumulation and melting of snow, and rain on snow. Such conditions are initiated and perpetuated by a persistent winter circulation anomaly in the North Pacific ocean that repeatedly steers alternately warm and cold storms into the region along a southerly displaced storm track. This scenario is enhanced by an active subtropical jetstream, common during ENSO periods.

\section{INTRODUCTION}

Extreme regional flooding occurred in Arizona during January and February, 1993. The widespread, high-magnitude flooding was the culmination of record amounts of precipitation (rain and snow) that fell statewide from a long succession of storms that began in early December, 1992. Anomalous and persistent patterns of atmospheric circulation steered approximately 16 separate storms over the state during this period.

The diverse physiography of Arizona, combined with the unusual climatic and meteorological conditions, resulted in an unusually long-lived and severe episode of flooding that affected most of the state. The 1993 event ranked as one of the most severe winter flooding episodes in state history, probably surpassed only by a similar episode in February 1891. In January and February, 
1993, record peak discharges were recorded at more than 35 stations (Figure 1, Table 1).

Unprecedented flow volumes and durations were associated with these discharges and with many that were not record floods (Figure 2). In some cases the absolute volume of flow was a more critical factor than high instantaneous peak discharges in relation to floodplain and reservoir management. On several occasions in 1993, large volumes of inflow overtaxed reservoirs and forced massive, dramatic releases of flood runoff from dams statewide. (Figure 3). The protracted flow durations enhanced severe erosion of some floodplain areas. On the middle Gila River, for example, it has been shown that the long-duration flow had considerably greater geomorphic impact on the floodplain than had a previous, shorter-lived flood with a greater instantaneous peak discharge (Huckleberry 1994). This situation may have been compounded by sustained releases from flood control structures.

The goal of this paper is to highlight the physical basis for these extreme floods within the large-scale and long-term context of their hydroclimatic origins and historical and prehistoric forerunners. In illustrating some of the more interesting flood phenomena, specific examples are presented that are assumed to be reasonably representative of conditions statewide.

\section{THE CAUSES OF FLOODING}

Flooding is the net result of the combination and interaction of three interrelated factors: (1) the short-term precipitation-delivering mechanisms that are the most immediate cause of the excessive runoff (flood hydrometeorology), (2) the large-scale and long-term climatic conditions and circulation patterns prior to and during the flood (flood hydroclimatology), and (3) the physiography, i.e., drainage basin characteristics of the stream systems which must accommodate the excessive runoff.

Flood hydrometeorology focuses on the sequence of weather events that are the most immediate -- or proximate -- causes of flooding. These short-term meteorological events emerge from a longer-term and larger-scale context which has been defined as "flood hydroclimatology" (Hirschboeck, 1988). Flood hydroclimatology places regional hydrometeorologic flooding activity in the context of its history of variation over a long period of time. It also examines the uniqueness of flooding events in terms of their antecedent conditions and the spatial framework of the regional and global network of changing combinations of meteorological elements such as storm tracks, air masses, pressure-height anomalies, and other components of the large-scale circulation. Consideration of floods in their hydroclimatological context allows individual flood 


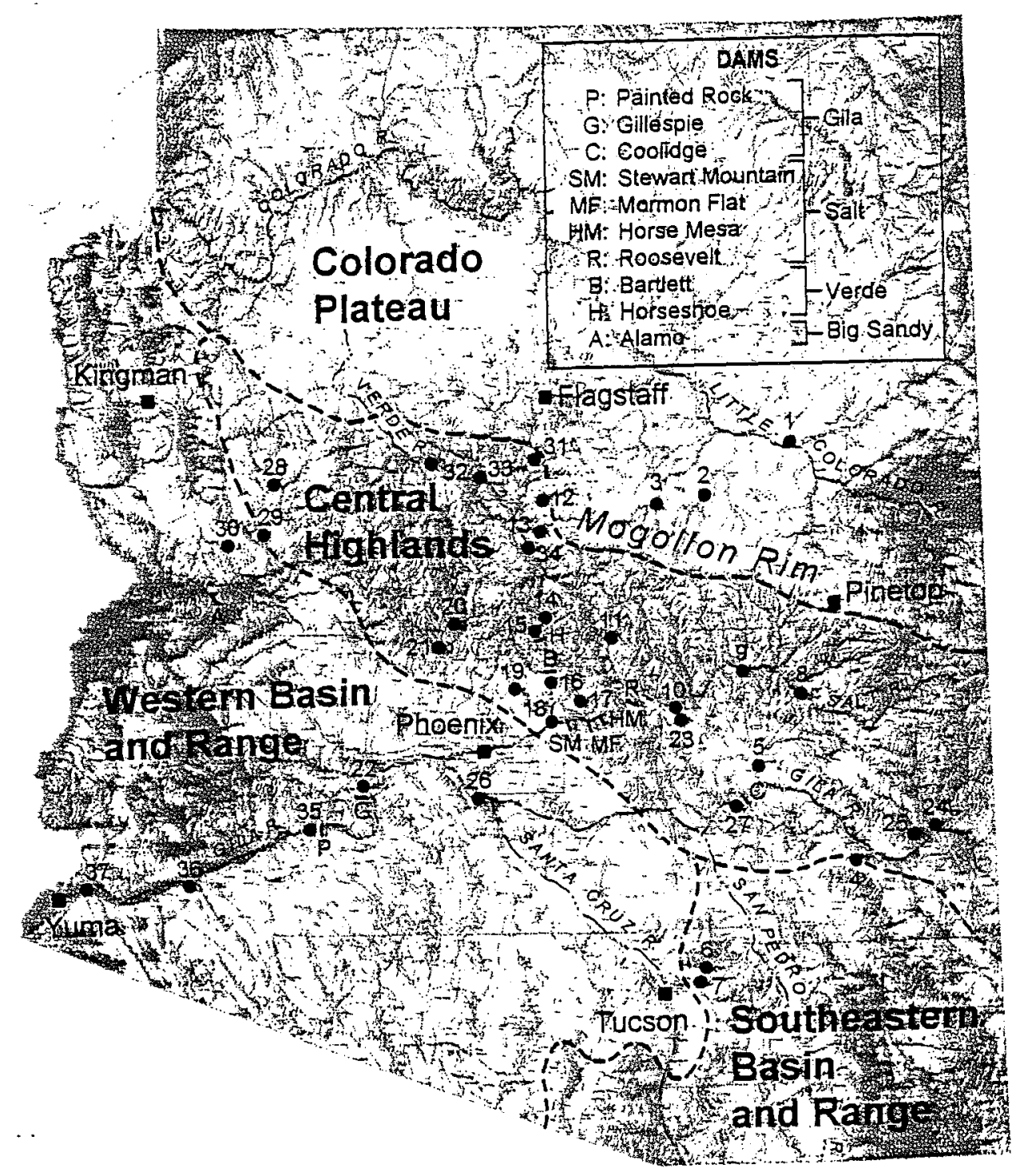

Figure 1 Map of Arizona showing physiographic regions, sites of record floods at stations with at least 10 years of record (numbered), the location of dams affected by the flooding, and the location of sites mentioned in the text. Each record flood site is described in Table 1. 


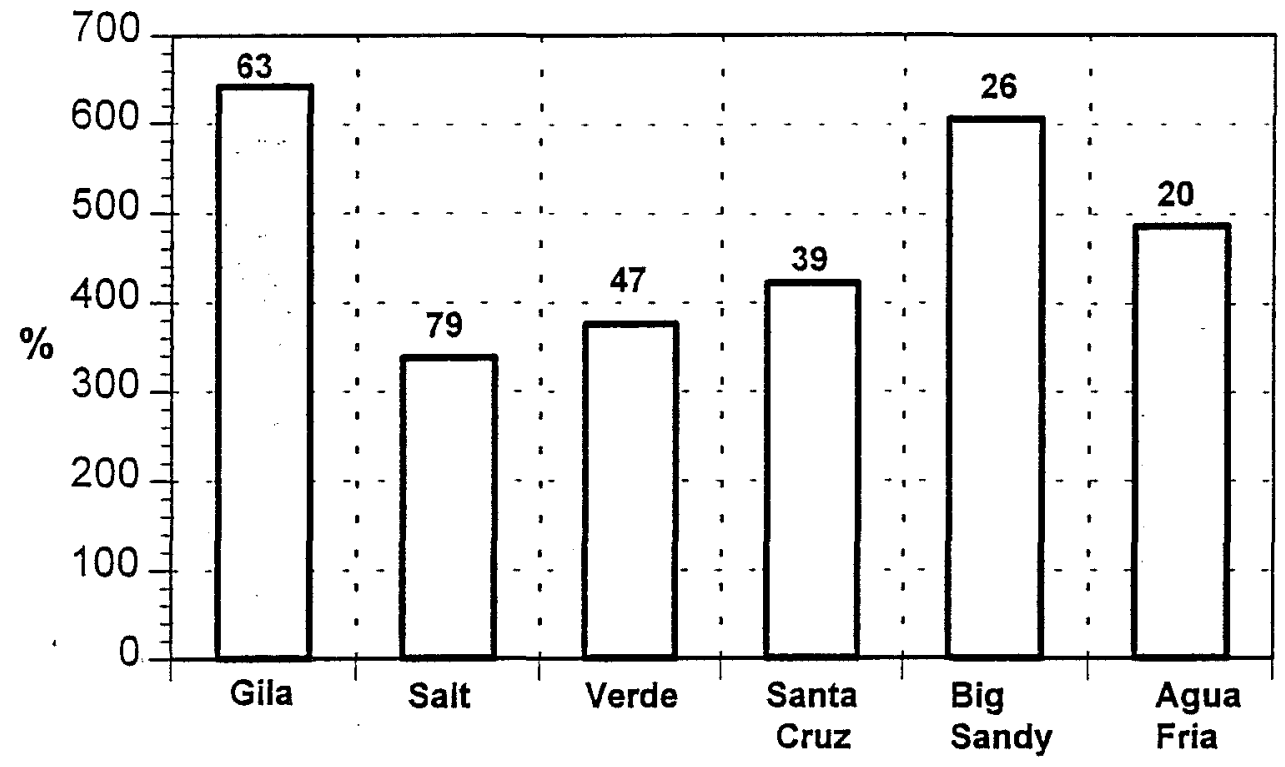

Figure 2. 1993 mean annual discharge expressed as a percentage of the long-term mean for selected, unregulated streams in Arizona. Numbers above the bars correspond to the length of record (years) on which the long-term mean is based. Data from USGS. 


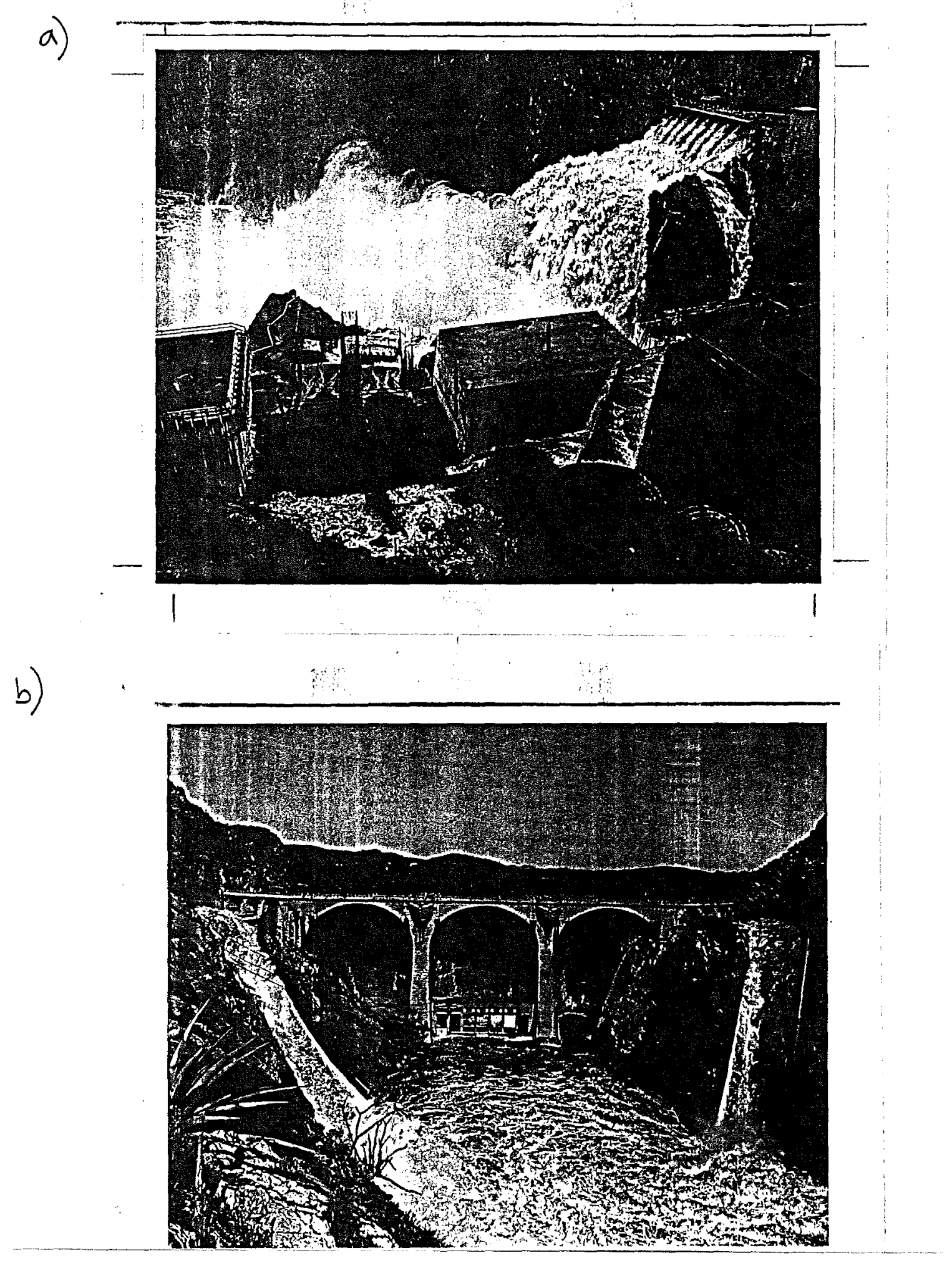

Figure 3. Photographs of two major dams in Arizona adversely affected by flooding during the winter of 1993. (A). Roosevelt Dam on the Salt River, January 19, 1993. (B). Coolidge Dam on the Gila River, January 16, 1993. Photos by the U.S. Bureau of Reclamation 



\begin{tabular}{|c|c|c|c|c|c|c|c|c|}
\hline Point & Site & USGS \# & $\begin{array}{r}\text { Area } \\
\left(\mathrm{km}^{2}\right) \\
\end{array}$ & $\begin{array}{l}\text { Peak Q } \\
\left(\mathrm{m}^{3} \mathrm{~s}^{-1}\right) \\
\end{array}$ & Date & $\begin{array}{l}\text { Record } \\
\text { Length }\end{array}$ & $\begin{array}{c}\text { rior Flood } \\
\text { Peak Q } \\
\left(m^{3} s^{-1}\right) \\
\end{array}$ & f Record \\
\hline 1 & Leroux Wash near Hobrook, AZ & 9397100 & 2,095 & 240 & 8-Jan & 13 & 215 & 24-Aug-92 \\
\hline 2 & Chevelon Creek near Winslow, AZ & 9397500 & 702 & 699 & 8-Jan & $35^{* *}$ & 564 & 18-Dec-78 \\
\hline 3 & Clear Creek near Winslow, AZ & 9398500 & 821 & 824 & 8-Jan & $42^{*}$ & 558 & 18-Dec-78 \\
\hline 4 & Frye Creek near Thatcher, AZ & 9460150 & 10 & 14 & 8-Jan & $17^{\star \star *}$ & 3 & 24-Aug-92 \\
\hline 5 & San Carlos River near Peridot, AZ & 9468500 & 2,657 & 1,552 & 8-Jan & $68^{* *}$ & 1,150 & 14-Mar-41 \\
\hline 6 & Sabino Creek near Tucson, $A Z$ & 9484000 & 92 & 365 & 8-Jan & $63^{\star *}$ & 219 & $6-\operatorname{Sep}-70$ \\
\hline 7 & Tanque Verde Creek near Tucson, AZ & 9484500 & 567 & 694 & 8-Jan & $27^{* *}$ & 360 & 18-Dec-78 \\
\hline 8 & Black River near Fort Apache, $A Z$ & 9490500 & 3,191 & 1,549 & 8.Jan & $45^{\star *}$ & 1,252 & $2-0 c t-83$ \\
\hline 9 & Salt River near Chrysotile, $A Z$ & 9497500 & 7,379 & 2,169 & 8-Jan & 71 & 1,994 & 18-Dec-78 \\
\hline 10 & Salt River near Roosevelt, $A Z$ & 9498500 & 11,153 & 4,050 & 8-Jan & 82 & 3,313 & 14-Mar-41 \\
\hline 11 & Tonto Creek near Roosevelt, AZ & 9499000 & 1,748 & 2,053 & 8-Jan & 55 & 1,739 & 15-Feb-80 \\
\hline 12 & Wet Beaver Creek near Rimrock, AZ & 9505200 & 287 & 453 & 8-Jan & 34 & 309 & 19-Feb-80 \\
\hline 13 & West Clear Creek near Camp Verde, AZ & 9505800 & 624 & 702 & 8-Jan & 30 & 634 & 18-Dec-78 \\
\hline 14 & Wet Bottom Creek near Childs, AZ & 9508300 & 94 & 209 & 8-Jan & 28 & 193 & $19-F e b-80$ \\
\hline 15 & Verde River below Tangle Creek, AZ & 9508500 & 14,227 & 4,106 & 8-Jan & 50 & 2,684 & $15-F e b-80$ \\
\hline 16 & Verde River below Bartlett Dam, AZ* & 9510000 & 15,032 & 3,115 & 8-Jan & 56 & 2,860 & 2-Mar-78 \\
\hline 17 & Rock Creek near Sunflower, AZ & 9510180 & 39 & 72 & 8-Jan & $12^{*}$ & 54 & 22-Dec-65 \\
\hline 18 & Verde River near Scottsdale, $A Z^{*}$ & 9511300 & 16,188 & 3,597 & 8-Jan & 34 & 2,775 & 16-Feb-80 \\
\hline 19 & Cave Creek near Cave Creek, AZ & 9512280 & 214 & 261 & 8-Jan & 15 & 110 & 1-Mar-91 \\
\hline 20 & Bouider Creek near Rock Springs, AZ & 9512830 & 98 & 283 & 8-Jan & 10 & 91 & 1-Mar-91 \\
\hline 21 & Humbug Creek near Castle Hot Springs, AZ & 9512860 & 155 & 170 & 8-Jan & 12 & 91 & 1-Mar-91 \\
\hline 22 & Gila River at Gillespie Dam, $A Z^{\star}$ & 9518000 & 128,594 & 3,682 & 9.Jan & 54 & 3,511 & $17-F e b-80$ \\
\hline 23 & Pinal Creek near Globe, AZ & 9498400 & 420 & 161 & 11-Jan & 15 & 83 & 9-Jul-81 \\
\hline 24 & Eagle Creek near Morenci, $A Z^{*}$ & 9447000 & 1,611 & 1,042 & 18-Jan & 51 & 1,031 & $2-0 c t-83$ \\
\hline 25 & Bonita Creek near Morenci, AZ & 9447800 & 782 & 552 & 18-Jan & 14 & 549 & $2-0 c t-83$ \\
\hline 26 & Gila River near Laveen, $A Z^{*}$ & 9479500 & 53,393 & 1,178 & 20-Jan & 54 & 991 & $4-0 c t-83$ \\
\hline 27 & Gila River below Coolidge Dam, $A Z^{*}$ & 9469500 & 33,375 & 830 & $21-J a n$ & 67 & 142 & $6-0 c t-83$ \\
\hline 28 & Francis Creek near Bagdad, AZ & 9424432 & 347 & 354 & 8-Feb & 10 & 193 & 25-Aug-88 \\
\hline 29 & Burro Creek near Bagdad, AZ & 9424447 & 1,557 & 1,566 & $8-F e b$ & 14 & 866 & 3-Mar-83 \\
\hline 30 & Big Sandy River near Wikieup, AZ & 9424450 & 7,076 & 1,946 & 8-Feb & 29 & 1,090 & $20-\mathrm{Feb}-80$ \\
\hline 31 & Oak Creek at Sedona, AZ & 9504430 & 603 & 657 & $19-\mathrm{Feb}$ & 14 & 586 & 12-Mar-82 \\
\hline 32 & Verde River near Paulden, $A Z$ & 9503700 & 5,569 & 657 & 20 -Feb & 32 & 445 & $20-F e b-80$ \\
\hline 33 & Verde River near Clarkdale, AZ & 9504000 & 8,130 & 1,507 & $20-\mathrm{Feb}$ & 35 & 1,433 & 21-Feb-80 \\
\hline 34 & Verde River near Camp Verde, AZ & 9506000 & 12,028 & 3,370 & $20-\mathrm{Feb}$ & $18^{* *}$ & 2,747 & 3-Mar-38 \\
\hline 35 & Gila River below Painted Rock Dam, $A Z^{*}$ & 9519800 & 131,857 & 906 & 26-Feb & 36 & 260 & 3-May-83 \\
\hline 36 & Gila River near Mohawk, AZ* & 9520360 & 143,564 & 773 & 1-Mar & 20 & 121 & $30-A p r-80$ \\
\hline 37 & Gila River near Dome, $A Z^{*}$ & 9520500 & 149,832 & 818 & 3-Mar & 36 & 136 & 18-Sep-63 \\
\hline
\end{tabular}

*Drainage regulated above station. Period of record corresponds to period of affected flow

* Period of record is not continuous

Table 1. Summary of record discharges in Arizona, January and February 1993. Only stations with more than 10 years of record are shown. Data from USGS. 
events to be linked to atmospheric phenomena operating at longer time scales and global spatial scales. Physiography is the terrestrial component of the three factors which generate floods. We use the term physiography to refer to all physical aspects of a drainage basin: topography (e.g. elevation distribution, relief, drainage density, basin shape), vegetation, geology, and location. These are the factors that influence the storage, distribution, and ultimate concentration of atmospheric moisture into runoff. Basin physiography is the integrating component that translates precipitation from discrete weather events, embedded in the larger scale circulation features, into flood peaks, flood volumes, and flow durations.

\section{FLOODING IN ARIZONA -- PHYSIOGRAPHY, CLIMATOLOGY, AND DRAINAGE}

The physiography and climatology of Arizona provide the framework for a spatially and temporally diverse flooding regime. In order to place the Arizona floods of 1993 in context, first we will provide an overview of the physiographic and climatic setting in which the floods developed. Arizona is comprised of three distinctively different physiographic regions: the Basin and Range, the Colorado Plateau, and the Central Highlands (Figure 1).

The Basin and Range province dominates the western and southeastern portions of Arizona. It is characterized by widely spaced mountain ranges of relatively limited extent separated by wide, low-lying valleys. Its boundary with the Central Highlands province to the east and north is defined by a marked discontinuity in the relative density of rugged, mountainous topography. The climate of the Basin and Range physiographic region varies from the arid Sonoran Desert in the west to the semi-arid desert grasslands of the southeast. The western Basin and Range is characterized by limited precipitation in all months with a slight bimodal seasonality. In winter, rainfall averaging less than $1 \mathrm{~cm}$ per month occurs when fronts from the Pacific Ocean traverse the state at latitudes far enough south to affect the region. The greatest precipitation occurs in mid-to-late summer when convectional showers dominate. Convective storms are active, but highly variable, dow to intense surface heating and a seasonal influx of moisture-laden air from the Pacific Ocean, Gulf of California, and humid regions of tropical Mexico during the so-called "summer monsoon." In some years, the summer precipitation season is enhanced and/or prolonged into fall by rainfall associated with excess moisture from tropical storms in the eastern North Pacific Ocean or Gulf of California. Streamflow is ephemeral, highly variable and prone to flash flooding in drainage basins which are not regulated. Winter snow accumulation and subsequent melting is not a major source of flood runoff. 
The southeastern portion of the Basin and Range has the highest and most closely spaced mountain ranges in the physiographic province. Elevations in this portion range from around 610 $\mathrm{m}(2000 \mathrm{ft})$ to greater than $3,048 \mathrm{~m}(10,000 \mathrm{ft})$ in some places. The slightly higher elevations lead to more abundant and more frequent rainfall due to orographic effects. Unregulated streams are often intermittent in their flow, and some perennial reaches can be found in the larger basins. The region experiences a precipitation maximum in summer and a secondary maximum in winter. In summer, exceptionally large flows and flash floods occur from convectional thunderstorms during seasonal monsoon influxes of atmospheric moisture from the Gulf of Mexico, humid regions of tropical Mexico, the Gulf of California, or the Pacific Ocean, as well as occasional excess moisture from eastern North Pacific tropical storms. In winter, frontal precipitation dominates. Some frontal passages are associated with warmer, subtropical atmospheric flow and yield only rainfall. Others are southerly displaced cold fronts which deliver rainfall to the valleys and snow to the upper elevations. During the course of a winter, streams which drain the highest ranges may experience some snowmelt runoff. This can be accelerated by rain falling on the snow during a warm winter storm passage.

The Central Highlands region is characterized by very rugged topography. It has closely spaced mountain ranges and deep canyons. Elevations range from around $305 \mathrm{~m}(1000 \mathrm{ft})$ to over $3,048 \mathrm{~m}(10,000 \mathrm{ft})$ on the highest peaks. The orientation of the Central Highlands is roughly northwest-southeast thus presenting a prominent orographic barrier to storms coming in from the southwest across the low desert. The Central Highlands are separated from the considerably less rugged Colorado Plateau by the Mogollon Rim, a distinct erosional escarpment along most of its length. The southwest face of the rim is riddled with deeply incised canyons that traverse the Central Highlands region and feed into two major drainage basins -- the Verde and Salt rivers. The precipitation regime differs from that of the Basin and Range region to the south by having much larger winter precipitation totals due to more frequent frontal passages. Although the months of July and August are the wettest on the average, precipitation totals from December through March are comparable, giving the area a balanced summer/winter bimodal precipitation regime. Influxes of moisture from occasional Pacific tropical storms can also affect this region and add to summer and fall precipitation totals. Streams that drain the rugged topography of the Central Highlands and Mogollon Rim are able to maintain perennial flow due to a precipitationenhancing orographic effect that activates summer convectional showers and fosters the 
accumulation of snow during winter frontal passages. In the larger drainage basins, substantial snow accumulations can have an important effect on winter and spring flooding. Snowmelt runoff and rain falling on snow is much more likely to generate flood runoff here than in the Basin and Range region to the south.

The Colorado Plateau is a relatively low relief, sparsely vegetated, high elevation portion of north-northeastern Arizona with widely spaced mesas, buttes, and small, isolated mountain ranges. It exhibits the same bimodal precipitation regime of the Central Highlands region, but lacks the strong orographic effect because of its less rugged topography. For this reason, the effect of downslope adiabated drying, and a more distant location from oceanic sources of moisture influx, the plateau is characterized by lower overall precipitation totals than the Central Highlands region, especially in winter. Streams in this northern part of the state flow in response to local convectional thunderstorms in summer, and precipitation from frequent frontal passages in winter. Intense convectional showers are a common source of flash flooding during the humid summer months. Occasionally in summer and fall, tropical storms provide a source of excess atmospheric moisture even as far north as the Colorado Plateau region.

\section{The Major Drainages}

The two largest river systems in Arizona are the Gila River basin and the Lower Colorado River basin (above its confluence with the Gila in western Arizona). The Gila basin includes most of the Basin and Range streams and those Central Highlands streams which drain toward the south and west away from the Mogollon Rim. The Lower Colorado basin includes the Colorado Plateau and is dominated by the Little Colorado and Colorado Rivers, as well as streams which drain northward away from the Rim.

Within the Gila basin, the Santa Cruz and San Pedro Rivers are the major systems draining the southeastern Basin and Range. They flow northward from source regions in Mexico (San Pedro River) and along the Arizona-Mexico border (Santa Cruz River). Tributary streams head in the high elevations of the southeastern mountain ranges, but most of the drainage area in the Santa Cruz and San Pedro basins is below 1,220 m (4000 feet).

The northern half of the Gila basin is dominated by the Salt-Verde River system. The entire Salt River Drainage basin -- which flows westward from its source in extreme eastern Arizona -is in the Central Highlands region. Most of the Salt's tributaries head on the Mogollon Rim. The 
Verde River heads on the Colorado Plateau, but the majority of the basin is within the Central Highlands. Most of the Verde's major tributaries occur as canyons that are deeply incised into the Rim. Both basins have large portions of their drainage areas above $1,830 \mathrm{~m}$ (6000 feet).

The Verde and the Salt river basins are the largest, unregulated basins in the state. The area above the gage located furthest downstream on the unregulated Verde is more than $14,227 \mathrm{~km}^{2}$ $\left(5493 \mathrm{mi}^{2}\right)$. The unregulated portion of the Salt drains a slightly smaller $11,152 \mathrm{~km}^{2}\left(4306 \mathrm{mi}^{2}\right)$. Below these points the rivers are extensively regulated for flood control, irrigation, and municipal water supply. The Salt and Verde Rivers join east of Phoenix where the name Salt River is retained for the trunk stream. Just west of Phoenix, the Salt River joins the Gila River. The Gila is the master drainage, ultimately draining $148,864 \mathrm{~km}^{2}\left(57,477 \mathrm{mi}^{2}\right)$. This is more than $50 \%$ of the total area of the state. The Gila River is also extensively regulated. In its unregulated portion, the river drains $11,470 \mathrm{mi}^{2}\left(29,707 \mathrm{~km}^{2}\right)$, much of it in New Mexico. The Gila River traverses the southern half of the state in an east-west direction. It joins the Colorado River at Yuma, Arizona.

\section{Hydroclimatic Flooding Regimes}

The interaction between seasonal climate and physiography in different regions of the state results in some interesting contrasts in the flooding regimes of the major drainages. Due to distinctive combinations of the climatic processes involved in the generation of floods in Arizona - i.e., frontal rainfall, convectional thunderstorm rainfall, tropical storm rainfall, and snowmelt -the flood records at various Arizona stream gages can be decomposed into hydroclimatically defined mixed distributions (Hirschboeck, 1985, 1987). This is an effective method for exploring the underlying physical basis for individual events in a gaged flood record and for better evaluating the kinds of hydroclimatic conditions that are likely to generate the most extreme events -- such as the floods of 1993.

To illustrate this "flood hydroclimatology" approach, Figure 4 depicts a comparison of the hydroclimatically decomposed flood records for the Santa Cruz River at Tucson, a drainage basin representative of the southeastern Basin and Range region, and the Verde River below Tangle Creek, a basin located principally in the Central Highlands region. The discharges are presented in the form of standardized dimensionless $z$ scores for easier comparison. The complete histogram of all peaks-above-base during the period 1950-1985 is shown for each stream on the far left of Figure 4, with the annual flood peaks distinguished from the other peaks above the partial 

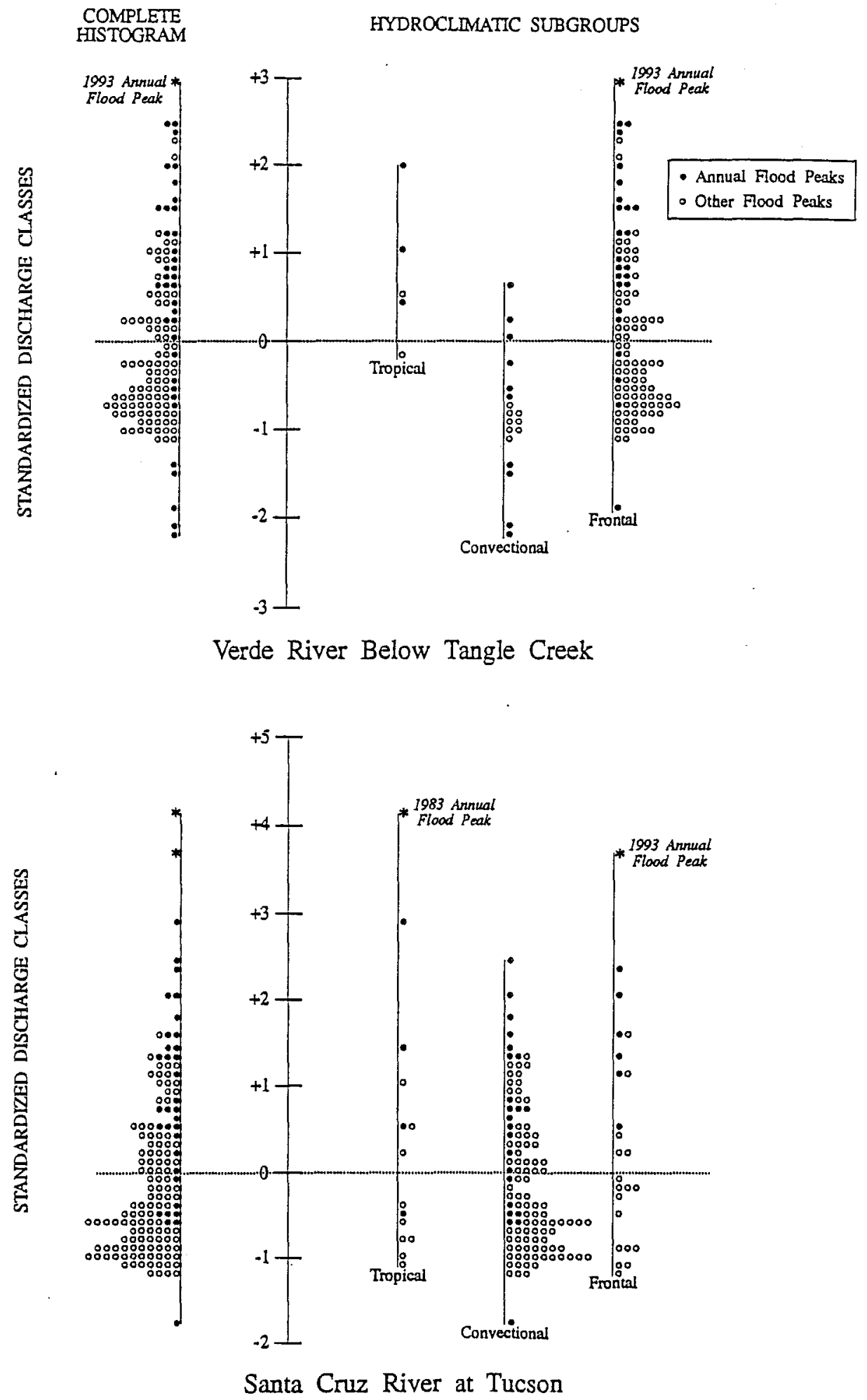

Figure 4. Decomposition of Verde and Santa Cruz flood histograms according to hydroclimatic cause of flood. 
duration series base. To the right of each stream's complete histogram, the same peaks have been regrouped into separate subgroup histograms according to what type of climatic process generated each flood: tropical storm rainfall, convectional rainfall, or frontal precipitation (rain and/or snow). Note that the 1993 annual peaks have also been plotted for each stream to show how they compare to the 1950-1985 gaged record.

This methodology shows clearly that summer flooding due to convectional rainfall is far more frequent in the southeastern Basin and Range region, while winter flooding due to frontal passages and snowmelt is more common in the Central Highlands region. This results from differences between the two regions in both the frequency of different types of synoptic meteorological events and physiographic factors. While winter frontal precipitation can occur throughout the state, the influence of fronts is greater in central and northern Arizona than southern Arizona. Because of their higher latitude location, these regions lie closer to the most common North Pacific storm tracks that typically steer fronts across the western United States in winter. This, coupled with the orographic effect of higher elevations, leads to a higher frequency of floods from frontal precipitation (rain and snow) in northern and central Arizona than is observed in southern Arizona.

This general pattern shows up in streams throughout both regions but it can be influenced further by basin-specific physiographic characteristics. For the two basins compared in Figure 4, the Verde basin has a larger contributing drainage area than that of the Santa Cruz: $14,227 \mathrm{~km}^{2}$ $\left(5493 \mathrm{mi}^{2}\right)$ vs. $5,755 \mathrm{~km}^{2}\left(2222 \mathrm{mi}^{2}\right)$. The Verde River's larger drainage area influences the number and size of front-generated floods, because as basin area increases, the importance of intense convectional showers as primary flood-producing events tends to decrease. Another factor that leads to a dominance of frontal flooding in the Verde basin is the percent of the basin at high elevations where snow accumulation and subsequent melting contribute to the runoff. Thirty percent of the Verde's contributing drainage area is above $1,830 \mathrm{~m}(6000 \mathrm{ft})$ in elevation, whereas only $1.8 \%$ of the Santa Cruz's drainage area is above this elevation.

This decomposition of the flood record into hydroclimatic subgroups yields some especially interesting information about the largest peaks in a stream's record. In the Verde River, the largest floods in the extreme upper tail of the histogram distribution -- including the 1993 flood -- are associated with the Verde's most common flood-generating climatic mechanism: frontal precipitation. In addition, tropical-storm related precipitation events, although rare, play a role in 
generating floods significantly greater than the mean. In the Santa Cruz basin to the south, floods are most likely to be generated by summer convectional rainfall. In contrast to the Verde, however, most of the floods in the extreme upper tail of the Santa Cruz's flood histogram were not generated by its most common flood-generating climatic mechanism. Instead the largest discharges resulted from rarer tropical-storm events (as in the record-breaking flood of October 1983) or by winter frontal events such as the 1993 floods under discussion here.

As illustrated in Figure 4, the extreme nature of the 1993 floods is underscored by evaluating them within the overall hydroclimatic context of flooding in Arizona. Hydroclimatically decomposed flood series for other Arizona streams suggest that winter frontal events are most likely to generate the largest floods of record in large basins of the Central Highlands region of the state. The events of winter 1993 clearly support this. However, even in the southern part of the state which tends to be dominated by heavy summer precipitation and a high frequency of summer floods the 1993 winter flood peaks in many cases ranked as some of the largest floods of record. This supports our general conclusion that in Arizona, front-generated winter precipitation is highly likely to be the cause of the most extreme floods of record in large basins (greater than about $1000 \mathrm{~km}^{2}$ ) throughout the state, even in areas that tend to experience their greatest frequency of flooding during the summer season.

\section{THE 1993 ARIZONA FLOODS}

The spectacular flooding which occurred throughout Arizona in January and February 1993 resulted from record precipitation totals from a high frequency of winter frontal passages. These fronts were steered across the state by an exceptionally active storm track, located unusually far

south. Frontal precipitation was frequent and heavy not only in the Central Highlands region, but throughout southern Arizona as well. Hence, one of the most important aspects of the 1993 floods was their great regional scope. Record floods were recorded statewide (Figure 1, Table 1) and, although the flood source areas were limited primarily to the Central Highlands and the southeastern Basin and Range, their impact was far-reaching due to the fact that the major drainages from these regions traverse extremely large portions of the state. The Little Colorado River, which drains most of the Colorado Plateau, experienced flooding in response to excessive runoff from basins that drain the northern side of the Mogollon Rim. Major peaks were not recorded on streams draining the remainder of the Colorado Plateau. With the exception of this 
area, the 1993 floods affected the entire state of Arizona. Historically, based on the longest gaged measurements, numerous streams had record or near-record peaks during this extreme event.

What combination of factors led to this major flooding event? How unusual was it within the context of the long-term climatic history and paleohydrology of flooding in Arizona? How likely is it for a similar event to occur in the future, given the uncertainty of either a naturally fluctuating or radically changing climate? We will examine these questions by presenting a detailed analysis of the hydroclimatic and physical aspects of the 1993 floods and then evaluating this information within the context of paleoflood evidence, regional historical peaks, and probable future climatic scenarios.

\section{Large-Scale Atmospheric Circulation and Antecedent Conditions}

The hydrometeorological, hydroclimatological and physiography-related factors that led to the 1993 Arizona floods emerged from a series of global- and regional-scale climatic events and antecedent conditions that developed prior to and during the January/February flooding episode. A key component of the episode was an unusually strong large-scale atmospheric circulation anomaly that developed in the extratropical latitudes of the eastern Pacific Ocean and persisted in various forms throughout the winter of 1992/93. Prior to this, during the previous winter of 1991/92, El Niño conditions had persisted with above-normal sea-surface temperatures (SST's) in the central and eastern tropical Pacific ocean. By mid-1992 the El Niño-Southern Oscillation (ENSO) index that characterizes the strength of the El Niño air-sea interaction had returned to normal although SSTs remained above normal in the western tropical Pacific (Bell and Basist, 1994). During December 1992 through February 1993, above-normal SSTs again expanded eastward in the tropical and subtropical Pacific Ocean and ENSO conditions redeveloped. Although not as strong as the previous winter's ENSO, winter 92/93 marked one of the longest periods of continuous warm SSTs on record for the tropical Pacific. The atmospheric circulation accompanying this SST anomaly was an enhanced subtropical jetstream that conveyed warm, moisture-laden air from the central equatorial Pacific to the southwestern United States.

Beginning in December, an anomalous high pressure area developed in the extratropical latitudes in the eastern North Pacific Ocean. This feature persisted throughout the winter in varying degrees. Its most common form was that of a "blocking" configuration in the Gulf of Alaska region which displaced one branch of the polar jetstream and associated Pacific storm 
track far to the north and another branch to the south, where it combined with the abovementioned enhanced subtropical jetstream. This split-flow configuration in the upper-level westerly flow led to above-normal extratropical cyclonic storm activity moving into the western United States at latitudes unusually far south.

Figures $5 \mathrm{a}$ and $5 \mathrm{~b}$ depict this anomalous and persistent atmospheric circulation pattern in January and February, respectively. The broad, lightly shaded arrows indicate the mean trajectories of the two branches of the split westerly flow at the $500 \mathrm{mb}$ pressure height level (roughly 5-6 km above sea level). The unusual nature of the circulation pattern in each month is revealed by the standardized anomaly contours which show how much higher or lower than normal the $500 \mathrm{mb}$ pressure heights were in each month and how the anomalous flow was steered into the western United States, i.e., counterclockwise around the eastern Pacific trough (low anomaly center) just west of California and clockwise around the blocking ridge (high anomaly center) in the Gulf of Alaska region. Also shown is the amount and trajectory of anomalous moisture delivery into the southwestern United States (in grams of water vapor/kilograms air/second) at low levels ( $850 \mathrm{mb}$ pressure height; usually below 1-2 km above sea level). In both January and February, the low-level atmospheric flow which transported this excess moisture generally followed the anomalous steering currents associated with the deep trough at the $500 \mathrm{mb}$ level. December's circulation, (not shown in Figure 5), also experienced a tendency toward a split flow circulation pattern with an anomalous trough in the eastern North Pacific west of California and a blocking ridge in the vicinity of the Gulf of Alaska. Although in December the transport of moisture into the southwest at low levels was not significantly above normal, the high frequency of frontal storms that traversed the southwest that month resulted in greater than normal precipitation amounts (Bell and Basist, 1994).

The persistence of this large-scale circulation anomaly throughout the winter and the frequent recurrence of the split westerly flow configuration had a direct effect on both the individual storms that delivered flood-producing precipitation to Arizona and the antecedent conditions that evolved over time within individual drainage basins. The net result was to make the basins more and more susceptible to flooding as the winter progressed. Depending on the configuration of the daily circulation, frontal passages during December 1992 through February 1993 were associated with either cold or warm storms. During cold fronts, precipitation at the higher elevations accumulated as snow, but when an intervening warm front passed through, the warmer 

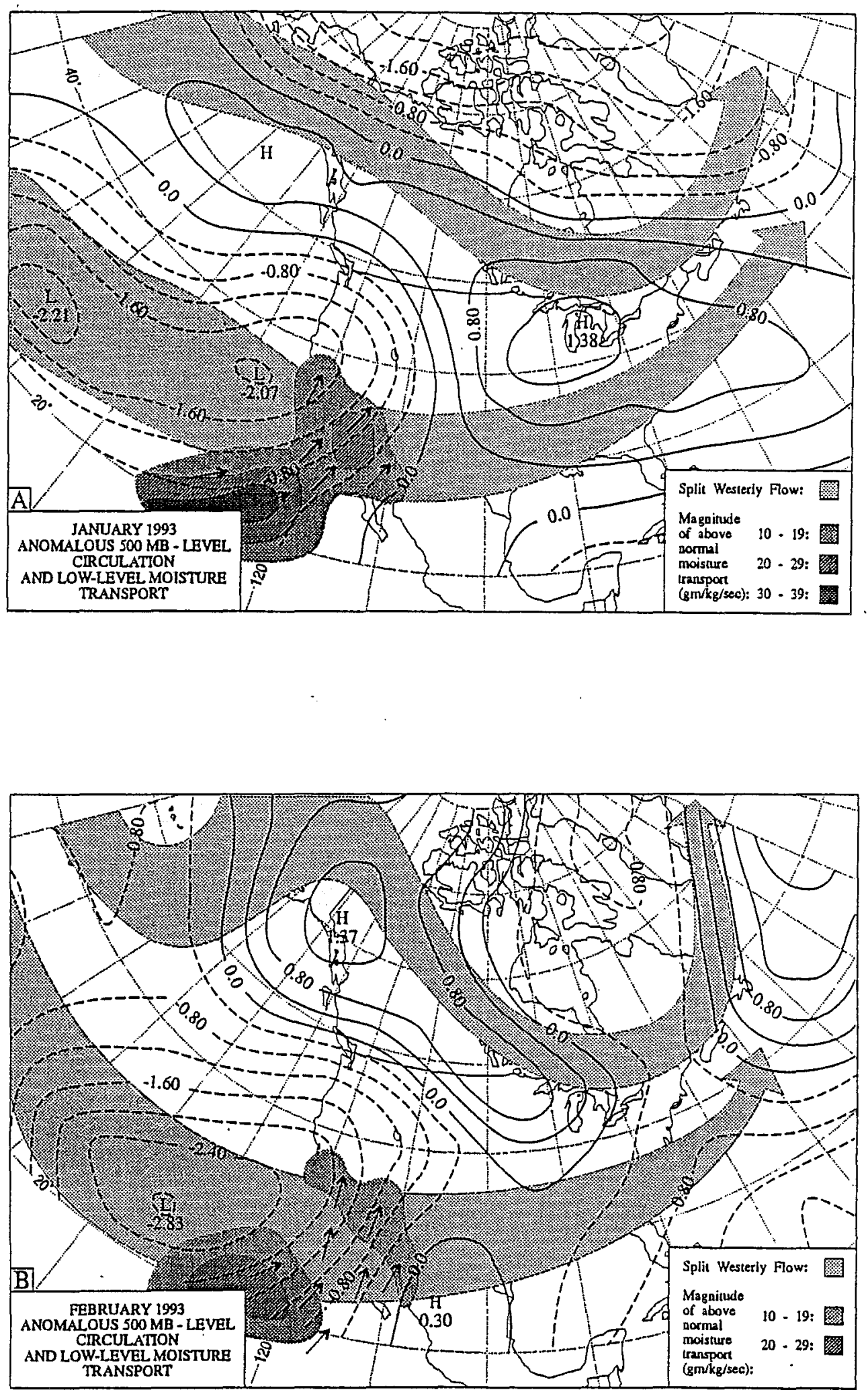

Figure 5. Anomalous upper-level atmospheric circulation and low-level moisture transport, (a) January, 1993; (b) February, 1993. Circulation contour units are standardized anomalies. (Moisture information from Bell and Basist, 1994.) 
temperatures would instigate snowmelt and any precipitation associated with the frontal passage would accelerate the melting process due to rain falling on the snow. This process repeated itself several times.

The persistence of the circulation anomaly in the eastern North Pacific ocean and its unusually placed storm track was the ultimate cause of the severity of the winter flooding in Arizona because of its influence on two key basin physiographic factors related to antecedent conditions: (1) soil moisture storage capacity and (2) snowmelt, especially in the Central Highlands region. In the first case, the unusual circulation's role in delivering a succession of storms led to progressive saturation of the drainage basins such that eventually soil moisture storage capacities were exceeded in even the largest catchments. Precipitation delivered by storms later in the season therefore immediately generated surface runoff. In the second case, shifts in the trajectory of the storm track across Arizona and its southward displacement resulted in alternating passages of warm and cold storms. This led to a complex sequence of events whereby snow accumulation and subsequent snowmelt, aided by rain falling on the snow, greatly augmented the amount of runoff.

Importance of rain on snow. One of the most important hydroclimatic processes affecting the 1993 flooding was rain falling on snow. The temporal distribution of successive flood peaks during the course of the winter appeared to be a direct result of this phenomenon and its relation to the alternation of warm and cold storms. This is illustrated in Figure 6 which shows the daily variation in snowpack depth from December through February, plotted with daily precipitation totals (rain and snow) for the Pinetop Fish Hatchery climate station in the Salt River basin and the Flagstaff $4 \mathrm{SW}$ climate station in the Verde River basin (see Figure 1 for locations). These stations are representative of conditions throughout most of the high-elevation areas in the state where flooding was generated, particularly in the Salt and Verde basins.

The relationship between snow depth and precipitation at each station indicates the importance of both the occurrence and the timing of rain on snow in generating the largest floods. The antecedent conditions for flooding were initiated in early December when a cold front passage associated with a deep trough and upper-level cutoff low delivered large amounts of precipitation (rain at low elevations, snow at high) and a deep snowpack accumulated. Snow depths remained fairly constant throughout most of the month, with some minor additions to and depletions from the snowpack occurring in response to typical winter cold front passages and intervening warming, respectively. However, during the last week of December, the El Niño- 


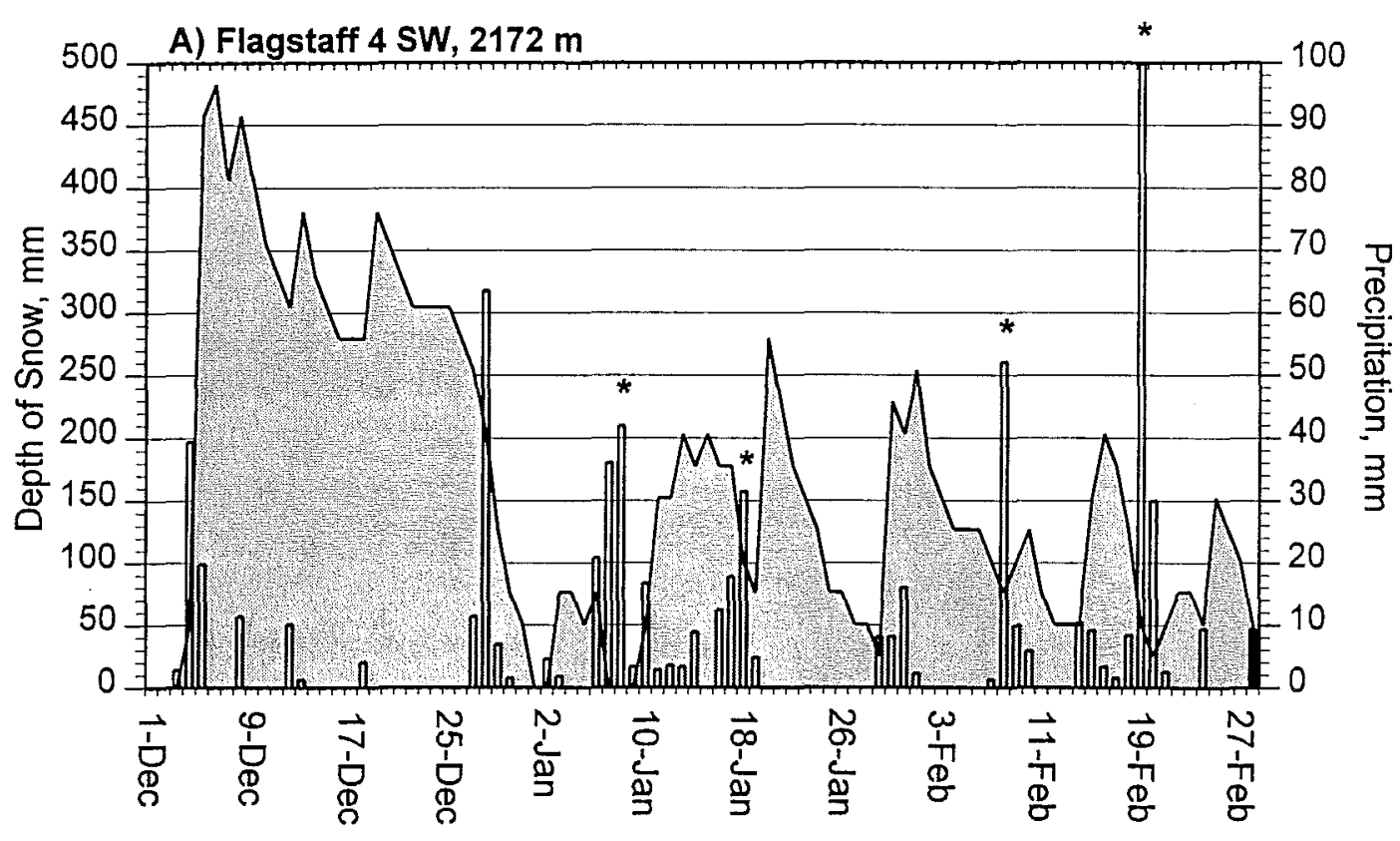

\section{$\square$ Precipitation $\square$ Depth of snow \\ $\star$ Large flood}

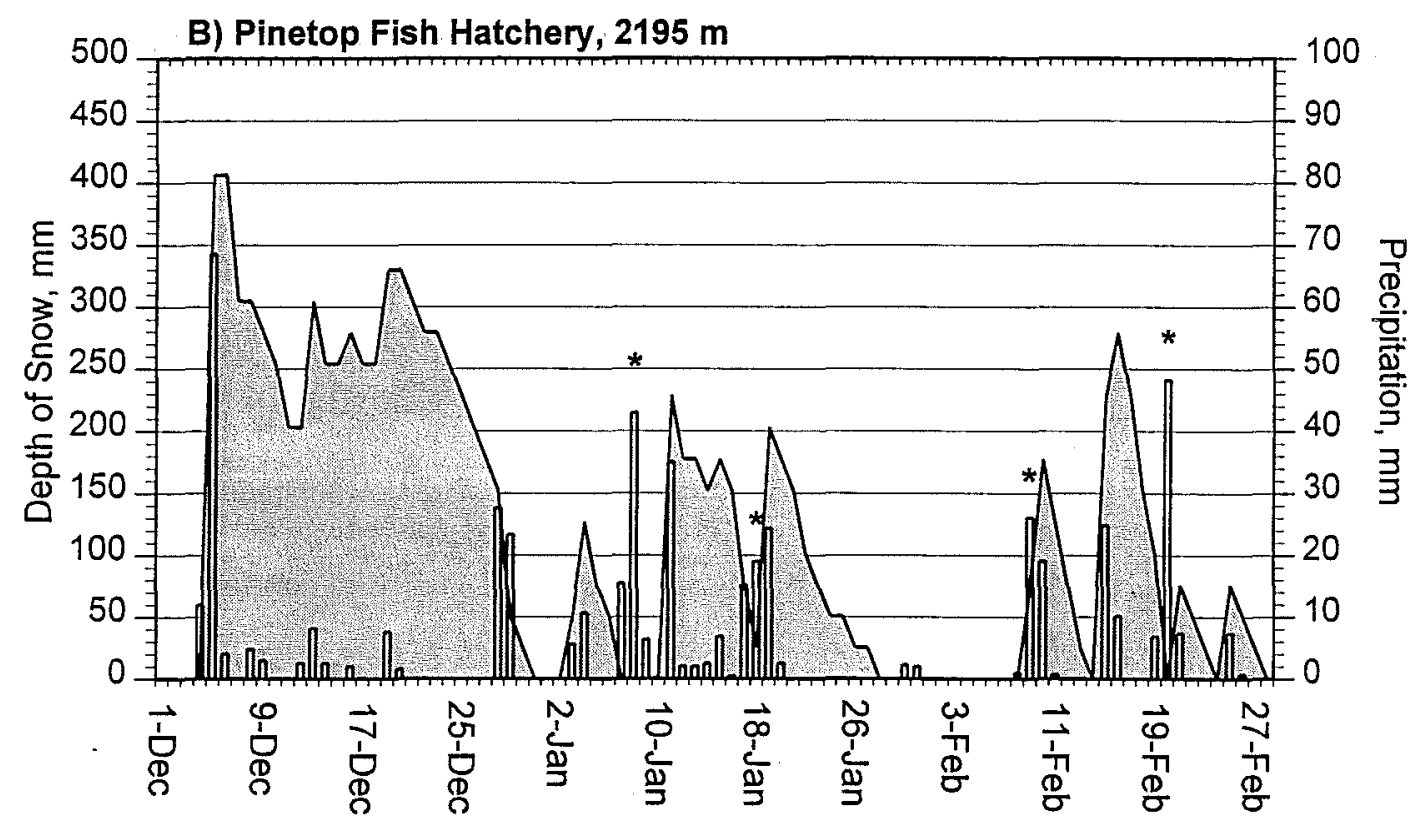

Figure 6. The relationship between precipitation and snow depth for two high-elevation stations in Arizona, December, 1992, through February, 1993. Precipitation shown corresponds to rain and snow. Data from NOAA. 
enhanced subtropical jetstream began to interact with the Pacific storm track more vigorously and a warm, subtropical storm moved into the state and dropped large quantities of rainfall. This subtropical event raised the snow level above about $2590 \mathrm{~m}$. Although depletion of the snowpack began during warming prior to the storm, the rain falling on the snow accelerated this depletion. Figure 6 shows, however, that much of the snowmelt followed the rain event rather than coincided with it, especially at Flagstaff. Although stream discharges rose in response to this event, major flooding was precluded, probably because significant amounts of rain did not continue to fall during or after the period of most rapid snowmelt. Nonetheless, this December precipitation and snowmelt thoroughly saturated the soil in drainage basins at all elevations throughout much of the state. This had important consequences for establishing the antecedent conditions which intensified subsequent flooding in January and February during four major storm episodes, which are indicated on Figure 6.

\section{The Four Major Storms}

The floods in Arizona were caused by at least 16 storms passing over Arizona during December, January, and February. Most of these contributed to runoff and were important for developing the antecedent conditions of soil saturation and accumulated snowpack necessary for the floods. However, four of the storms were the principal catalysts for the largest pulses of flooding that occurred during January and February. The number of individual storms that entered the region and the relative position of each storm track in relation to the position and characteristics of previous storms was reflected in the distribution of flood peaks throughout the state during this time period. Many streams had record or near record peaks in early January, others had them in early February and/or late February. Some basins in the central portion of the state had peak floods in response to each of the four major storm episodes that occurred. These same basins also flooded in response to some of the less regionally significant storms that occurred in between the major storm episodes. Figure 7 provides an illustration of this rather complicated scenario. It depicts normalized hydrographs for selected basins throughout the state and shows that the streams in the Central Highlands region best exhibited the four-peak flooding response.

In examining the precipitation patterns during January and February, we separated the four major storms as follows: (1) January 6-9, (2) January 13-19, (3) February 7-10, and (4) February 


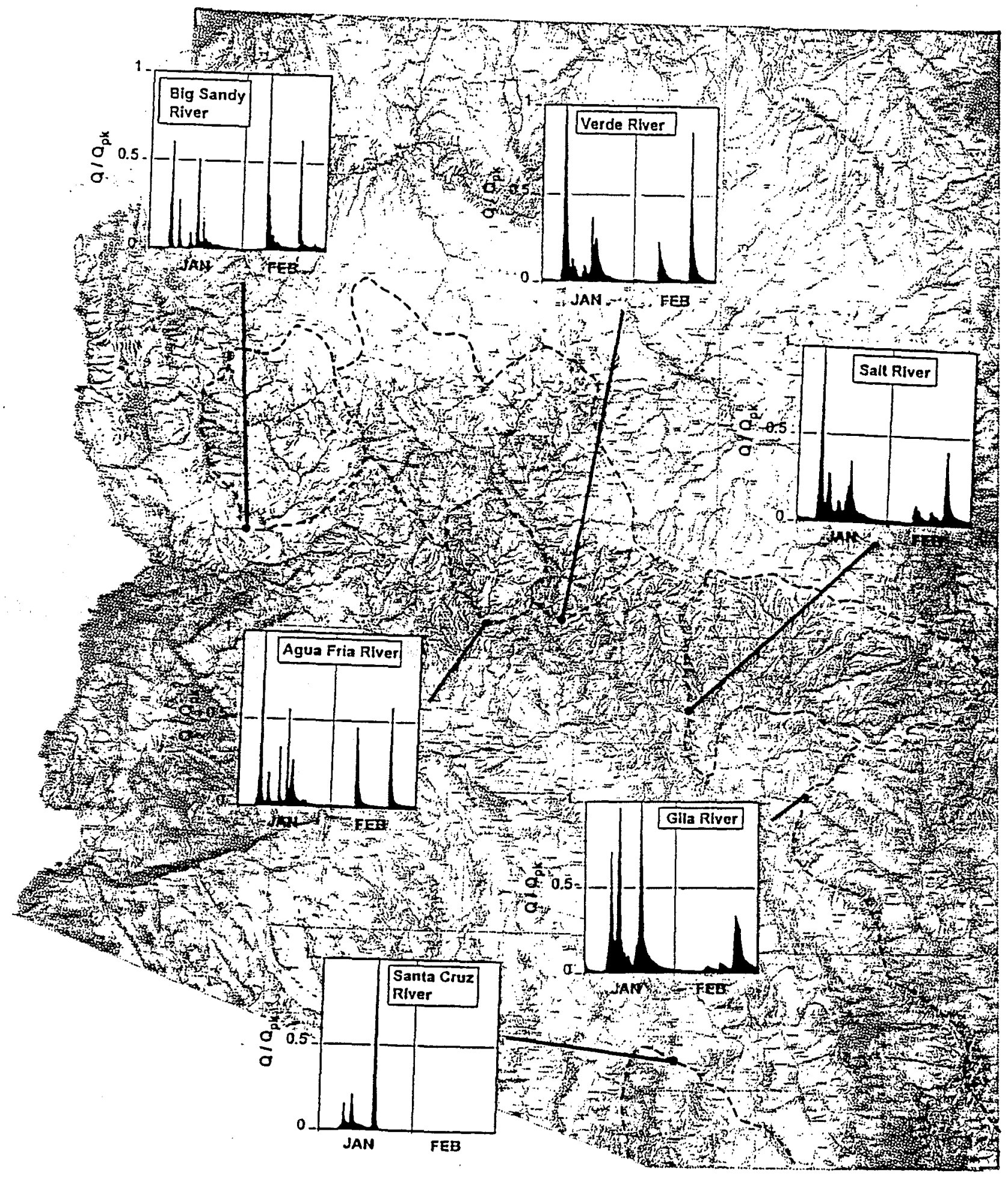

Figure 7. Map showing the spatial and temporal distribution and relative magnitude of flood peaks at selected (unregulated) basins throughout Arizona, January through February, 1993. The vertical axis shows the ratio of hourly discharge to the maximum discharge in the two month period. Based on provisional data from USGS. 

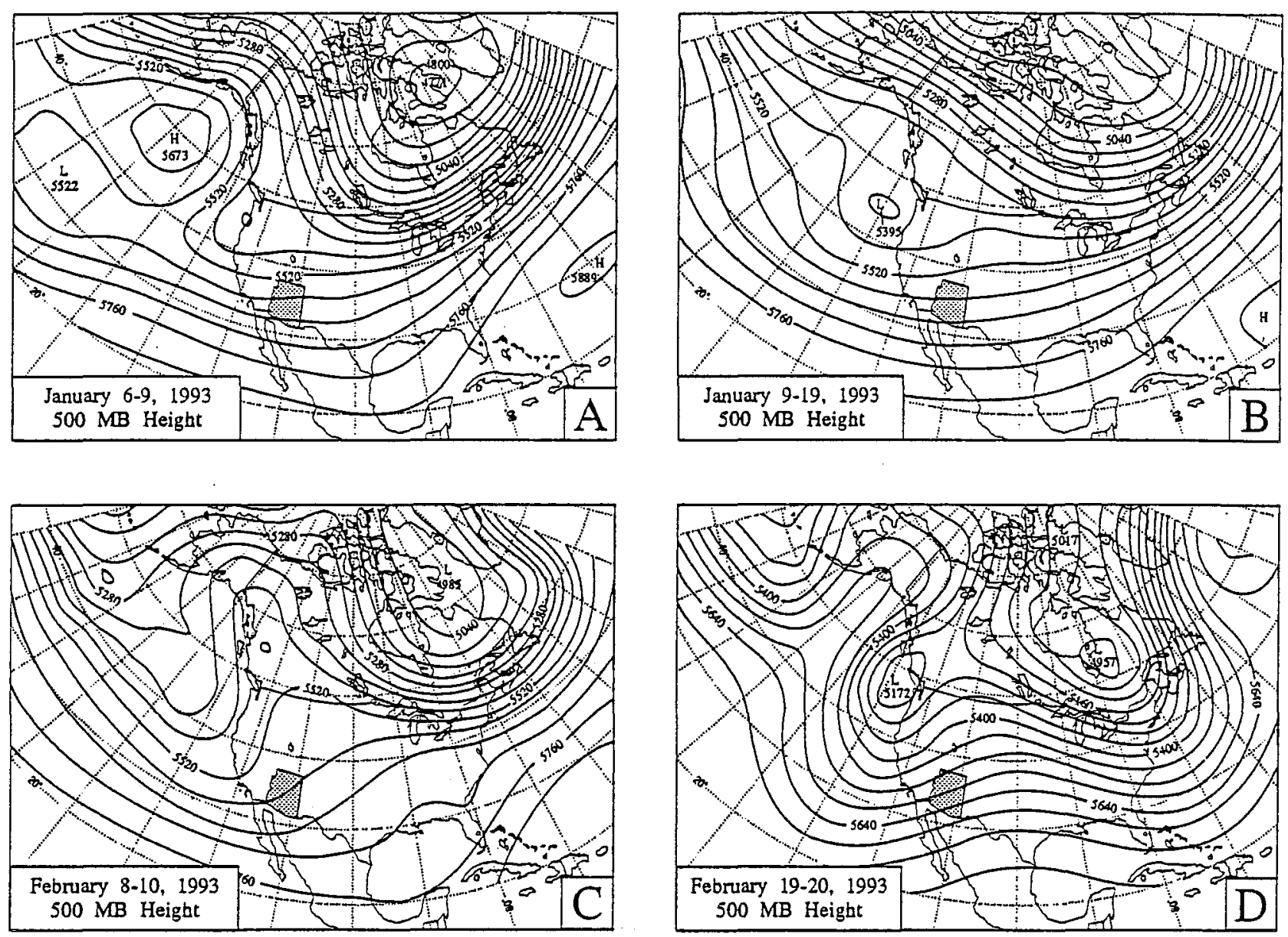

Figure 8. Composite 500-mb pressure heights for four storm episodes. Units are geopotential height in meters above sea level. 

18-21. These time periods were chosen in a way that best isolated the precipitation most directly associated with the major flooding episodes. We have however, omitted some storms that were locally significant and regionally important in the development of antecedent conditions. Composite $500 \mathrm{mb}$ upper-air circulation maps for periods roughly coinciding with these four storm periods are shown in Figure 8 and isohyet maps for the four storm episodes are given in Figure 9. The upper-air circulation maps show that a split westerly flow played a role during each of the four storm episodes. During the two main January storms (Figures 8a and b), a persistent upper-air high pressure ridge in the Gulf of Alaska region was coupled with an equally persistent upper-air low pressure trough immediately to the south. This configuration displaced the southern branch of the North Pacific storm track to lower-than-normal latitudes so that storms and abovenormal moisture (Figure 5a) were transported, directly across Arizona. The two February storms (Figures 8c and d) were also guided by an upper air ridge and trough pattern, but during these episodes the Gulf of Alaska ridge took the form of an omega-shaped blocking high pattern, and the attendant low pressure trough dug deeply into subtropical latitudes, conveying warm, moisture-laden air into the southwest from a more southerly trajectory, followed by the passage of a cold front as the trough moved through.

January 6-9. Following the precipitation that fell in December (particularly in the last week), the first major storm in January was the most widespread. It followed a brief period during which temperatures dropped, precipitation fell, the freezing level dropped to $1,525 \mathrm{~m}(5000 \mathrm{ft})$ and more snow accumulated at high elevations. On the $6 \mathrm{th}$, however, the snow level retreated to higher than $2,900 \mathrm{~m}$ when precipitation began to fall during the passage of a warm front associated with a disturbance of predominantly subtropical origin which was steered into Arizona by the southerly displaced branch of the split westerly flow. This system continued to deliver large quantities of rain for three days with maximum depths recorded on January 7 th. The timing of snowmelt and precipitation was optimal for flooding. The event virtually eliminated the snowpack in highelevation portions of most drainage basins, assisted by rain falling on the snow and relatively mild temperatures associated with the storm. More importantly, considerable rain continued to fall after the snowpack was melted. This combination of events, coupled with the melt event at the end of December, culminated in the most regionally significant period of flooding in the entire two-month episode, and arguably the largest such episode since 1891. Most of the record peaks recorded in the state were due to this storm (Table 1). Rainfall was particularly intense in the 
Central Highlands and in the higher ranges of the southeastern Basin and Range (Figure 9a). Very large basins draining the Central Highlands (i.e., Salt and Verde) had exceptionally large floods, while flooding on the Santa Cruz River in the southeast was not as severe (Figure 7). This storm event also served to perpetuate the antecedent conditions of soil saturation and minimal runoff storage capacity that would be critical in generating floods from subsequent weather events, even those with modest rainfall totals.

January 13-19. The widespread and heavy precipitation of the January 6-9 storm was followed by a similar, but less extreme, rain-on-snow event in the $3 \mathrm{rd}$ week of January. It culminated in flooding on the 19th. During this period several fronts passed through Arizona, steered along by the southerly displaced upper-air westerly flow. The rainfall associated with these storms was heavy in the southernmost part of the state, as well as in portions of the Central Highlands (Figure 9b). Major flooding occurred on the Santa Cruz River during this episode and the Gila River received a second pulse of peak flow, only days after the first flood crest had attenuated (Figure 7). Figure 6 indicates that at Flagstaff, the relation between precipitation and snowmelt was less optimal for flooding than that of the early January event. The snowpack was not depleted and, in fact it began to increase near the end of the storm period. Rainfall did not occur during the subsequent snowmelt. At Pinetop, conditions were slightly more favorable for flooding in that initially, more melting was concurrent with rainfall. However, by the end of the episode, snow was accumulating.

February 7-10. A shift in the configuration of the large-scale circulation preceded the first major storm episode in February. The high pressure anomaly in the Gulf of Alaska region shifted slightly to the east and increased in amplitude, bringing the axis of the ridge over western Canada (Figure 8c). This was associated with a southward movement of the eastern North Pacific trough and an increase in merdionality (north-south/south-north) flow in the circulation. The result was the continued conveyance of subtropical flow and moisture into the southwest (Figure 5b) which was directed northward into Arizona behind a warm front and rapidly followed by a cold front moving in from the west as the trough passed through. This synoptic situation was especially effective in delivering large amounts of precipitation to western, northwestern and central parts of Arizona (Figure 9c). Basins in these areas, such as the Big Sandy and Agua Fria Rivers experienced a third floodwave during this episode and the Big Sandy and several of its tributaries 

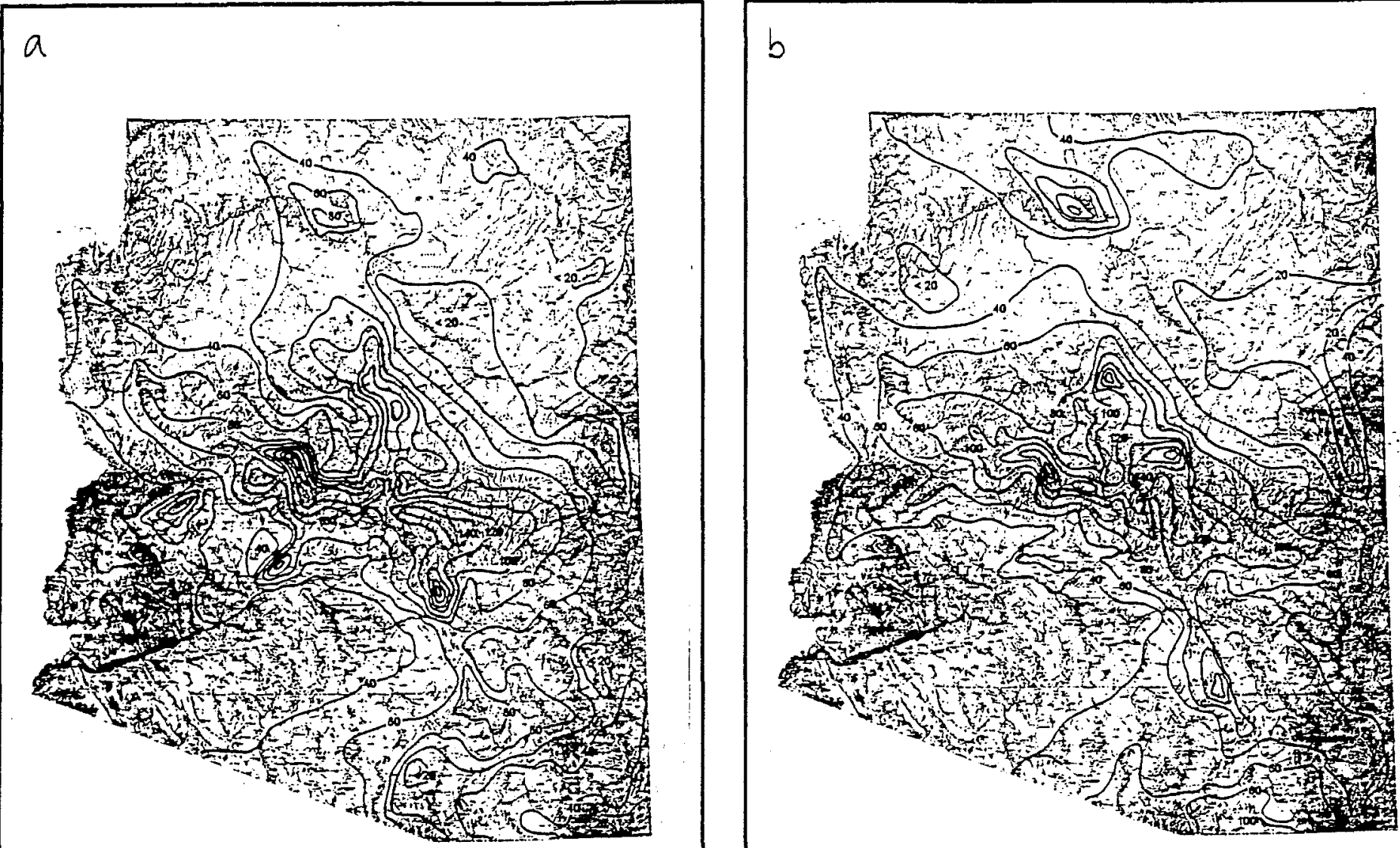

Figure 9. ' $\quad$ Isohyetal maps for the 4 periods of major regional flooding in Arizona, JanuaryFebruary, 1993. (A) January 6-9; (B) January 13-19; (C) February 7-10; (D)

C February 18-21. Isohyets based on data from NOAA, the Maricopa County Flood Control District, and the Salt River Project. Depths in mm.
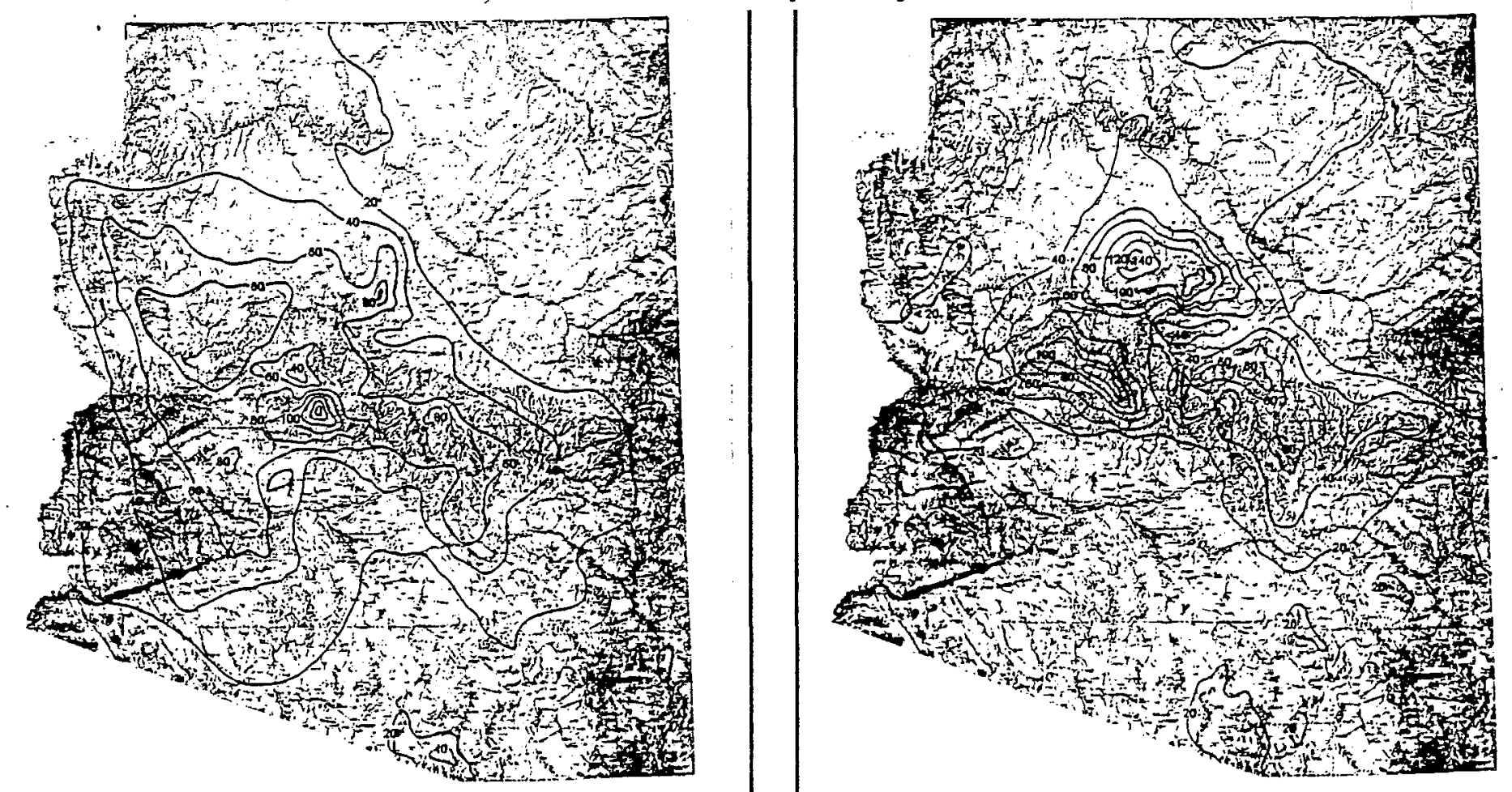
recorded peaks of record. (Figure 7, Table 1). This flooding was probably due to relatively localized, moderate to heavy precipitation on thoroughly saturated ground and only partially enhanced by snowmelt. During the cold front passage that marked the end of this event, some precipitation was delivered in the form of snow as seen at Flagstaff and Pinetop where snow levels decreased to $2135 \mathrm{~m}$ and snowpack depths increased (Figure 6).

February 18-21. As late February approached, the blocking high pressure anomaly returned to its earlier position over the Gulf of Alaska, still forcing a split flow in the westerlies and a trough displaced to lower latitudes of the eastern North Pacific (Figure 8d). Warming occurred in Arizona due to the southwesterly flow under this configuration and on February 17th, relatively rapid melting of the accumulated snowpack occurred due to a regional increase in average daily temperature (near $50^{\circ} \mathrm{F}$ at Flagstaff). Beginning late on February 18th, this melting episode was dramatically punctuated by precipitation from the last major storm (Figure 9d). The rapid passage of two fronts in a two-day period produced heavy precipitation over localized portions of the Central Highlands and, in particular, over the central Mogollon Rim in the general vicinity of Flagstaff. This area received extremely high daily totals of precipitation on the 18th and 19th that were characterized, at Flagstaff at least, by prolonged periods of relatively intense rainfall. The heavy rain fell on the melting snowpack and resulted in the rapid generation of immense quantities of runoff. Extremely large floods occurred on several streams draining these localized areas. The runoff was concentrated in a small portion of the Verde River basin. However, it was sufficient to generate the flood of record at the Verde River gaging stations at Paulden, Clarkdale, and Camp Verde (Table 1, Figure 1). It also amounted to the second largest flood ever recorded at the gage below Tangle Creek. A flood of this magnitude coming from such a small portion of the basin bespeaks of the extreme conditions that existed at the time and thus the importance of preceding events in December, January, and most of February.

The overriding importance of rain on snow in the generation of the 1993 floods, especially in the large basins of the Central Highlands, indicates that this process is a significant factor in the generation of extremely large floods. The strong correspondence between streamflow, snowmelt, and precipitation from December through February is illustrated quite well in Figure 10. Here the daily values of snowmelt and precipitation at Flagstaff are plotted with the average daily discharge of Oak Creek near Cornville, Arizona. This figure aptly illustrates the sensitivity of streamflow to the timing and relative magnitude of the rainfall in relation to the snowmelt. It suggests that the 


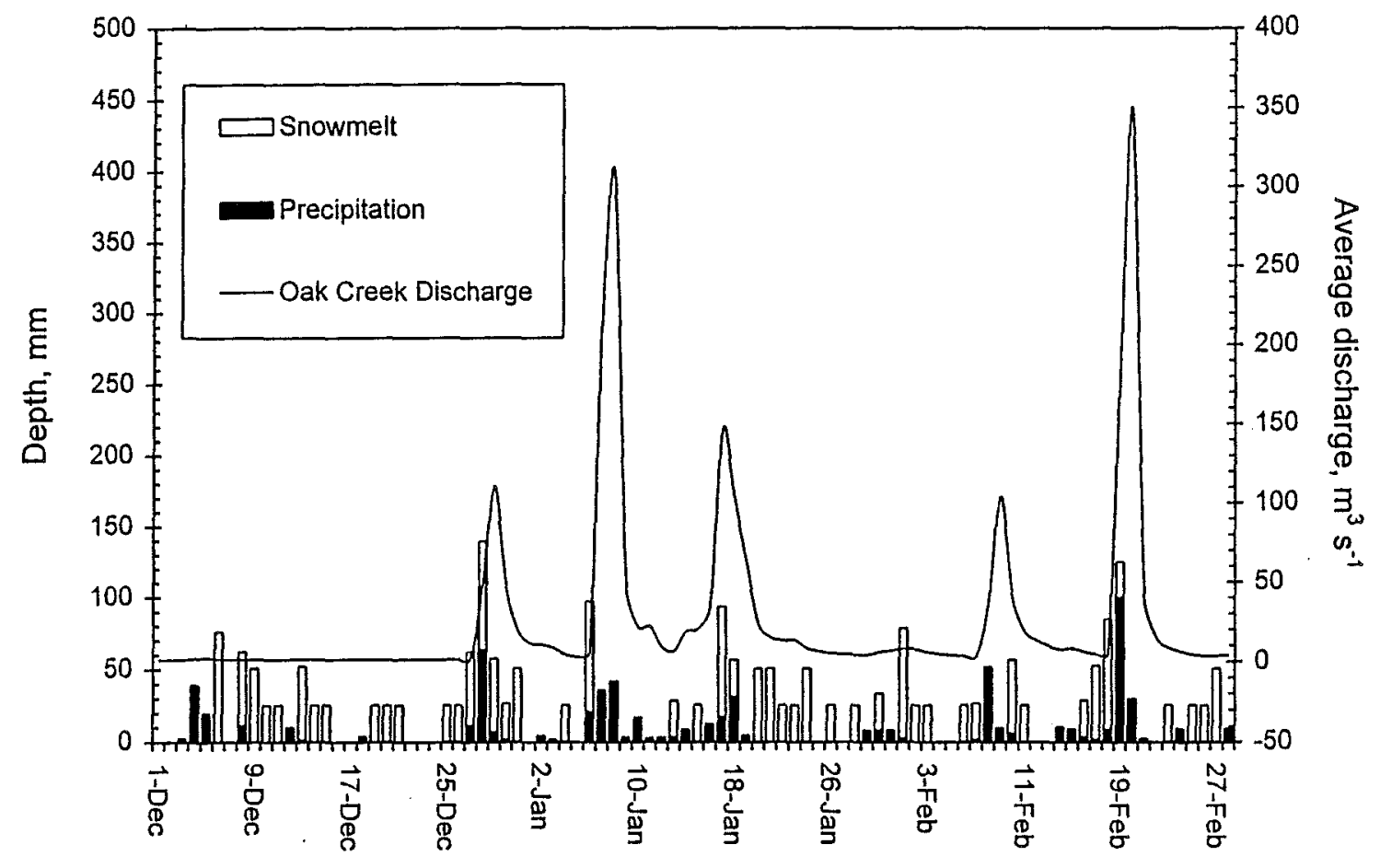

Figure 10. Snowmelt and precipitation at Flagstaff, Arizona, compared to average daily discharge of Oak Creek near Cornville, Arizona. Snowmelt is the change in the depth of the snowpack, and not the actual water content of the melt. Data from NOAA and USGS. 
largest flood peaks will occur when rain falls on snow, accelerating the melting process, and then continues to fall.

\section{THE 1993 FLOODS IN THE VERDE RIVER BASIN}

The remaining discussion of the 1993 winter flooding episode in Arizona will focus on flooding in the Verde River basin during January and February. The Verde River basin provides an excellent detailed perspective on many of the important characteristics of the flood episode. Extreme record-breaking discharges were recorded at all gages along the Verde River and on most of its principal tributaries during January and February 1993 (Figure 11). Because of its size, spatial distribution, and diverse physiography, flooding in different portions of the basin exhibited important aspects of the spatial and temporal variation that characterized the flooding throughout the state. Additionally, post-1993 flood studies and past research on flooding on the Verde River allows us to make generalizations about the relative magnitude of the 1993 floods with respect to the largest floods known to have occurred over the last $1000+$ years.

\section{Gaging Records from the Verde River Basin}

The Verde River basin spans nearly $15,000 \mathrm{~km}^{2}$ of central Arizona. Its headwaters and the headwaters of many of its tributaries encompass a large portion of the Colorado Plateau, but the Central Highlands constitute the bulk of the flood-producing portion of the basin. Four continuous recording gages are located along the Verde River. The uppermost gage is near Paulden, AZ (Figure 11). Its contributing drainage area is $5,569 \mathrm{~km}^{2}$, which is about $40 \%$ of the total basin area. It records runoff draining the Colorado Plateau and a northeast-facing portion of the Central Highlands region. Despite its size, little contribution from this portion of the Verde basin is actually reflected in the peak discharges at the gages downstream; in fact, flood peaks at Paulden often follow, rather than precede, those at the next gage downstream by several hours. This lag is probably due to the relatively elongated shape of the upper basin, circuitous drainage routes, and minor storage effects of Sullivan Lake, a small, natural lake just upstream of the gage (Chin et al, 1991).

Below Paulden, the next gage is near Clarkdale, Arizona. Its contributing drainage area is $8,130 \mathrm{~km}^{2}$ which accounts for about $60 \%$ of the total basin area or $30 \%$ of effective flood peakproducing area (i.e. the area below the gage at Paulden). About $75 \%$ of the area between Paulden and Clarkdale is drained by Sycamore Canyon and Hell Canyon. Sycamore Canyon is one of the 


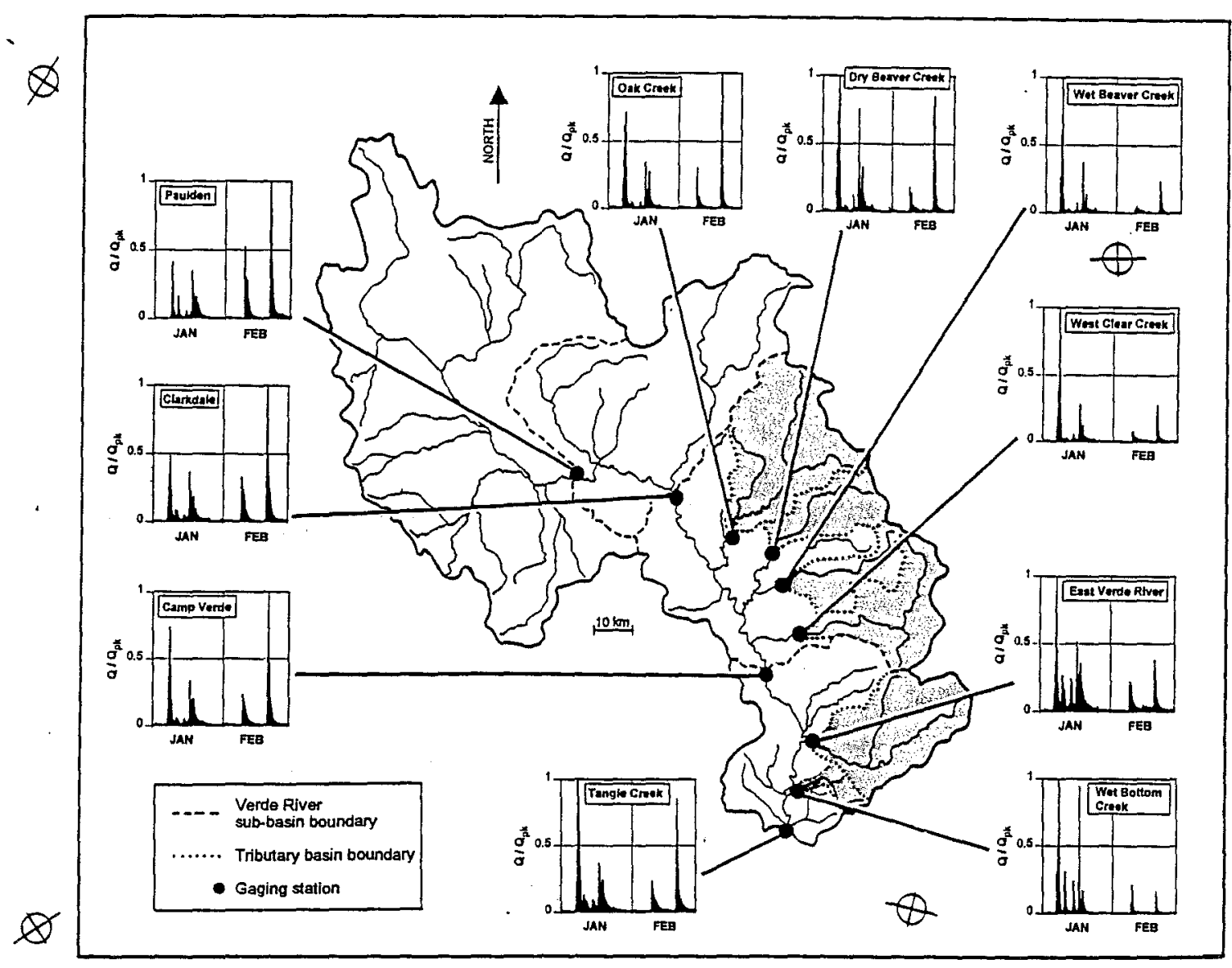

Figure 11. Spatial and temporal distribution and relative magnitude of flood peaks at all gaging stations in the Verde River Basin, January-February, 1993. Vertical axis shows the ratio of the hourly discharge to the maximum discharge recorded in the two month period. Based on provisional data from USGS. 
largest single tributaries in the Verde River system. It enters the Verde from the north approximately $2.7 \mathrm{~km}$ above the gage. During the 1993 events, Sycamore Canyon and Hell Canyon probably accounted for much more than $50 \%$ of the runoff at the Clarkdale gage. Unfortunately neither stream is gaged.

The gage below Clarkdale is near Camp Verde, Arizona. Its contributing drainage area is $12,028 \mathrm{~km}^{2}$, which is $85 \%$ of total basin area or $75 \%$ of the effective area. Between Clarkdale and Camp Verde, four relatively large, gaged tributaries enter the Verde River: Oak Creek $\left(920 \mathrm{~km}^{2}\right)$,

Dry Beaver Creek $\left(368 \mathrm{~km}^{2}\right)$, Wet Beaver Creek $\left(288 \mathrm{~km}^{2}\right)$, and West Clear Creek $\left(624 \mathrm{~km}^{2}\right)$ (see shaded portion of Figure 11). They account for about $55 \%$ of the drainage area between the mainstem gages of Clarkdale and Camp Verde. Each tributary drains high elevation terrain on the Colorado Plateau above the southwest face of the Mogollon Rim. Other small, ungaged tributaries from the northeastern side of the Central Highlands also enter the river between the gages but their relative contribution is small in relation to the Rim tributaries.

The final gage on the unregulated portion of the Verde River is located below Tangle Creek. It records runoff from a total of $15,170 \mathrm{~km}^{2}$, including an additional $2200 \mathrm{~km}^{2}$ below the Camp Verde gage. The majority of this area is within the rugged interior of the Central Highlands and the difference in the hydrographs between Camp Verde and Tangle Creek primarily represents differences in the relative amounts of runoff contributed by the Mogollon Rim and interior Central Highland portions of the basin. Two gaged tributaries enter in this reach: the East Verde River $\left(857 \mathrm{~km}^{2}\right)$ and Wet Bottom Creek $\left(94 \mathrm{~km}^{2}\right)$ (shaded on Figure 11). Many ungaged tributaries also enter in this part of the basin, and they can account for large contributions of runoff.

\section{Flood Hydrographs in the Verde River Basin: January and February, 1993}

The map of the Verde drainage basin in Figure 11 shows normalized hydrographs for each gaging station within the basin. The hydrographs exhibit variable responses to the two-month series of storms. The flood response of the Verde Basin is reflective of the statewide pattern depicted in Figure 8. Each gaged basin was affected by each flood-producing storm to some degree, and some basins responded to almost every precipitation event in the two month period. The most pronounced characteristic of the basin-wide response is the relative difference between the early January and late February peak discharges within different portions of the basin. The normalized hydrographs indicate that most of the gages, with the exception of the Verde River at 
Paulden and Clarkdale, recorded relatively large floods in early January; however, for most sites in the middle and upper portions, the peak in late February was the largest.

The early January and late February peak discharges at the Tangle Creek gage constituted the first and second largest recorded peaks at this site, respectively. Their extreme magnitudes were reflected in a massive accumulation of flood debris in a broad alcove less than one kilometer above the gage (Figure 12). A comparison of the actual discharge hydrographs at different gages along the main stem of the Verde (Figure 13) suggests that different source areas contributed to the peak discharge recorded at the Tangle Creek gage (located furthest downstream) during both major floods. In fact, examination of hydrograph and precipitation data suggests that the relatively small area between Camp Verde and Tangle Creek constituted more than $65 \%$ of the early January peak. In contrast, during the late February flood, it appears that a small portion of the basin between Paulden and Camp Verde contributed more than $95 \%$ of the peak recorded at Tangle Creek.

The Early January Event. The early January event is the largest recorded discharge at the gage below Tangle Creek, and the third largest discharge recorded at the gage near Camp Verde. The discharges were 4,106 $\mathrm{m}^{3} \mathrm{~s}^{-1}\left(145,000 \mathrm{ft}^{3} \mathrm{~s}^{-1}\right)$ and $2,478 \mathrm{~m}^{3} \mathrm{~s}^{-1}\left(87,500 \mathrm{ft}^{3} \mathrm{~s}^{-1}\right)$ respectively. At the Tangle Creek site, the only officially recognized flood larger than 1993 was the flood of February, 1891, which is listed as $4,248 \mathrm{~m}^{3} \mathrm{~s}^{-1}\left(150,000 \mathrm{ft}^{3} \mathrm{~s}^{-1}\right)$. Interestingly, the occurrence of peak discharge at the Paulden, Clarkdale, and Camp Verde gages followed that at the downstream Tangle Creek gage by varying amounts. Because the peak at the Camp Verde gage followed the peak at Tangle Creek by four hours, we can assume that only a portion of the rising limb of the Camp Verde hydrograph contributed directly to the peak recorded downstream (Figure 13a, Table 2). This suggests that an immense amount of runoff from the interior Central Highlands had to have been introduced to the river between the two stations (on the order of $2,690 \mathrm{~m}^{3} \mathrm{~s}^{-1}$ ). The occurrence of maximum discharge later in the afternoon at the gage near Camp Verde and at most of the middle and upper basin tributary gages contributed significantly to the sustained high flow and enormous volume recorded at Tangle Creek, where the discharge exceeded 3,960 $\mathrm{m}^{3} \mathrm{~s}^{-1}$ $\left(140,000 \mathrm{ft}^{3} \mathrm{~s}^{-1}\right)$ for more than 4 hours and exceeded $3,400 \mathrm{~m}^{3} \mathrm{~s}^{-1}\left(120,000 \mathrm{ft}^{3} \mathrm{~s}^{-1}\right)$ for more than 10 hours.

The lag between the peaks at Camp Verde and Tangle Creek was probably due to variations in the spatial and temporal distribution of precipitation within the basin. The most pronounced 


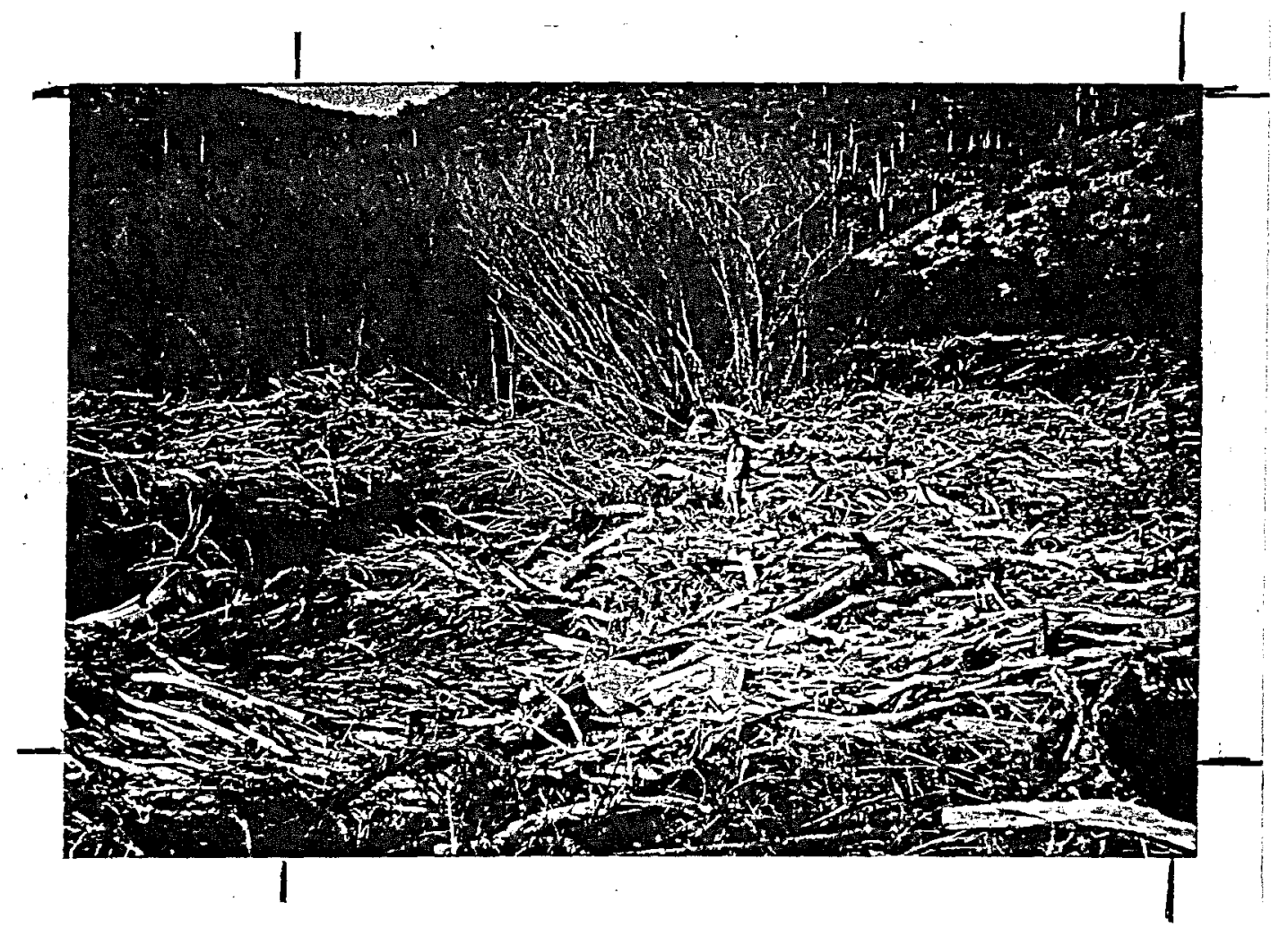

Figure 12. Large debris pile on lower Verde River, March 10, 1993. Photo by P. A. Pearthree, Arizona Geological Survey. 

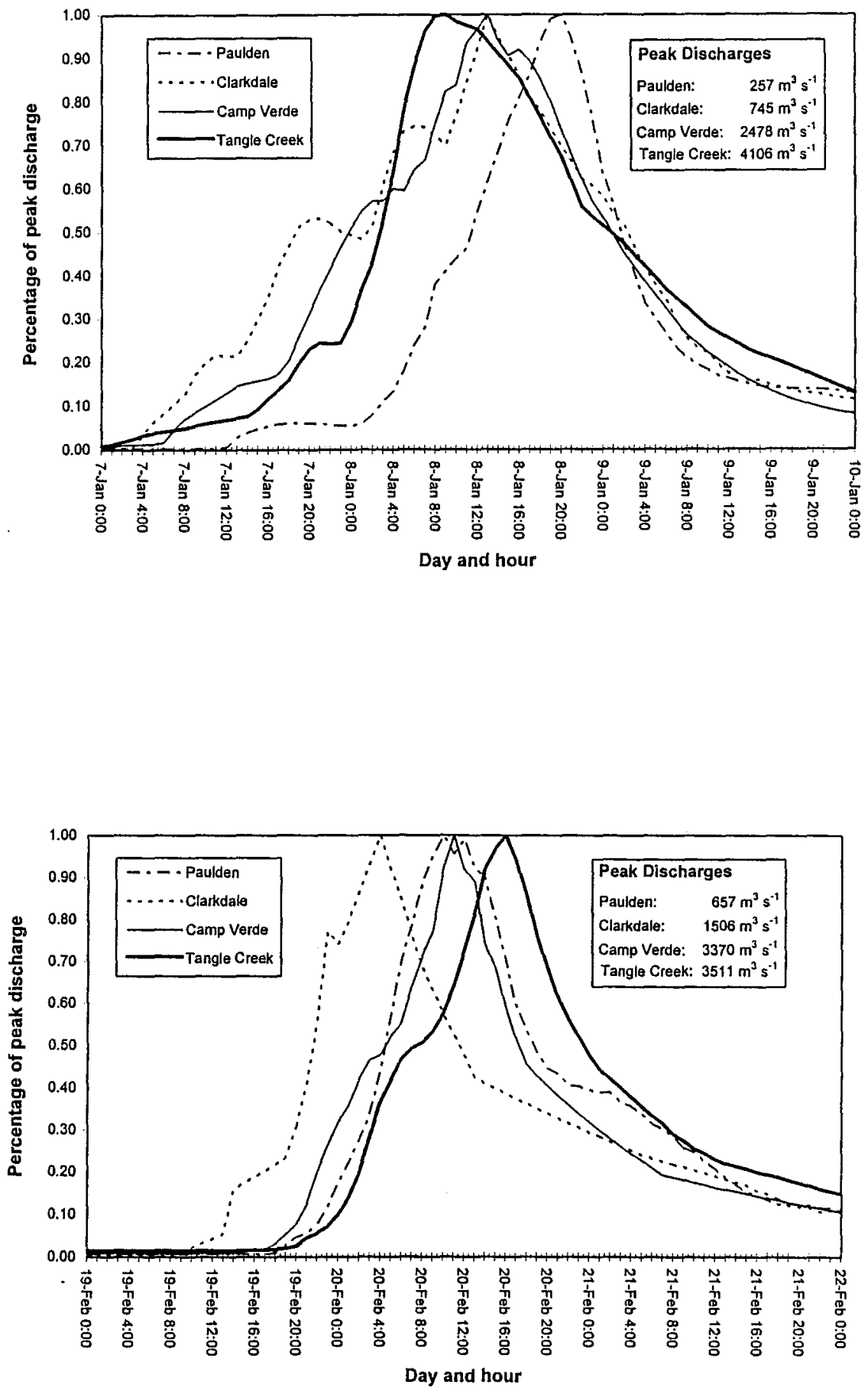

Figure 13. Normalized hydrographs from gaging stations on the Verde River, (a) January 7-9, (b) February 1921 . Based on provisional data from USGS. 
variations in the intensity of precipitation occurred primarily in the upper and middle basin and may have played a significant role in limiting the peak discharge of the early January event at Tangle Creek. A lull in precipitation recorded at rain gages near Flagstaff and Oak Creek Canyon corresponds to a distinct trough that can be observed in the hydrographs for January 7-8 of each of the Rim tributaries (not shown). The trough separates an initial peak, which comprised a portion of the early morning maximum flow below Tangle Creek, from a second, higher peak which comprised the early afternoon peak at Camp Verde and contributed to the sustained high flow at Tangle Creek.

The Late February Event. The late February event exceeded the magnitude of the early January flood at most of the gaging stations in the upper and middle portion of the basin. The limited spatial extent of this storm is evident in the distribution of flood peaks, and can be inferred from the precipitation distribution in Figure 9d. The sharp precipitation gradient is reflected in the strikingly different relative magnitudes of the floods at Wet and Dry Beaver creeks, two basins along the Mogollon Rim which are relatively close together (Figure 11). At the Tangle Creek gage, the flood of February 19, 1993 was $3,510 \mathrm{~m}^{3} \mathrm{~s}^{-1}\left(124,000 \mathrm{ft}^{3} \mathrm{~s}^{-1}\right)$, which is the second largest peak recorded at this site. At the gage near Camp Verde, the peak discharge was $3,370 \mathrm{~m}^{3}$ $\mathrm{s}^{-1}\left(119,000 \mathrm{ft}^{3} \mathrm{~s}^{-1}\right)$, which is the largest discharge recorded there. In striking contrast to the early January flood, examination of hydrological and meteorological data suggests that the vast majority of the peak and volume of the late February flood came from only a small part of the portion of the basin between Paulden and Camp Verde (Figure 13b). Most of the runoff in the late February flood came from Oak Creek, Dry Beaver Creek, Sycamore Canyon, and Hell Canyon. The runoff was relatively flashy as compared to the early January event, thus the total flow volume was considerably less at each gage site (e.g., less than about $50 \%$ of the total volume of the January flood at Tangle Creek). Gage records clearly indicate the importance of Oak and Dry Beaver Creeks; however the critical roles of Sycamore Canyon and Hell Canyon can only be inferred by comparing the Paulden and Clarkdale hydrographs. Figure 13 and Table 2 show that there is a significant lag in the timing of the peaks at Paulden and Clarkdale, with the upstream station (Paulden) peaking after Clarkdale in both the January and February events. This implies that little of the runoff at the Paulden gage was a source for the peak discharge at Clarkdale in either event. In the largest flood in late February, the discharge increased from less than about 113 to $1,510 \mathrm{~m}^{3} \mathrm{~s}^{-1}\left(4,000\right.$ to $\left.53,200 \mathrm{ft}^{3} \mathrm{~s}^{-1}\right)$ between the gages at Paulden and Clarkdale. It is likely 


\section{Summary of 1993 Flood Discharges in the Verde River Basin}

\begin{tabular}{|c|c|c|c|c|c|c|c|c|}
\hline Site & $\begin{array}{c}\text { January 8, } \\
1993 \text { Qpk }\end{array}$ & Time & $\begin{array}{c}\text { January 17, } \\
1993 \text { Qpk }\end{array}$ & Time, & $\begin{array}{c}\text { February 9, } \\
1993 \text { Qpk }\end{array}$ & Time & $\begin{array}{c}\text { February 20, } \\
1993 \text { Qpk }\end{array}$ & Time \\
\hline Verde nr Paulden & 9060 & 30 & 7670 & $15: 00$ & 11500 & $8: 0$ & 23200 & \\
\hline Verde nr Clarkdale & 26300 & 13.00 & 19700 & $7: 00=$ & 17600 & 445 & $\underline{53200}$ & \\
\hline Oak Creek & 18500 & 1145 & 8880 & $5: 15$ & 7840 & 245 & 26000 & \\
\hline Dry Beaver Creek & 11600 & 9.15 & 8800 & $315=$ & 2140 & 045 & 9870 & 515 \\
\hline Wet Beaver Creek & $\underline{16000}$ & 6.30 & 5980 & 6.00 & 876 & $18: 30$ & 3790 & 130 \\
\hline West Clear Creek & 24800 & $8: 00$ & 6990 & $6: 00$ & 1990 & 19.00 & 6900 & $100=$ \\
\hline Verde blw Camp Verde & 87500 & $13: 00$ & 40600 & 1230 & 27600 & $10: 45$ & 119000 & +1100 \\
\hline East Verde River & 20100 & $\begin{array}{l}7,00 \\
4\end{array}$ & 10400 & 745 & 4470 & 7115 & 7650 & 2.45 \\
\hline Wet Bottom Creek & 7380 & 7900 & 6970 & 730 & 1560 & 1530 & 1200 & \\
\hline Verde blw Tangle $\mathrm{Ck}$ & 145000 & $8 \pm 30$ & 53300 & 18.30 & 33600 & $16: 00$ & 124000 & $16: 00$ \\
\hline
\end{tabular}

Table 2. The magnitude and timing of peak discharges in the Verde River Basin, January and February 1993. Data from USGS. 
that much of this runoff came from Sycamore Canyon and Hell Canyon which comprise almost $75 \%$ of the area between the gages. Meteorological data from Flagstaff and Williams, Arizona, near the upper watershed of Sycamore Canyon, show that the rainfall and flooding conditions in the basin may have been equally (or more) extreme than those in the watershed of Oak Creek (which is $25 \%$ smaller than Sycamore Canyon).

These differences in the timing of flood peaks indicates that in both the early January and late February events, less than $50 \%$ of the basin contributed to the peak discharges recorded at Tangle Creek. If the ineffective area above the Paulden gage is ignored, this value drops to about $25 \%$. In the case of the January event, runoff delivered from the entire basin eventually contributed to an immense volume of runoff; but in the late February case, the delivery of runoff was much more limited in space and time, so the flow duration and total volume were considerably lower at Tangle Creek. It is clear from the basis of these two events that a larger flood could be generated under similar but more optimal circumstances in the Verde River basin. Paleoflood hydrology provides a framework from which to address the possibility for larger floods by directly examining evidence for them in the geological record.

\section{PALEOHYDROLOGICAL CONTEXT OF THE 1993 FLOODS}

Paleoflood hydrology is a geological approach to the study of the magnitude and/or frequency of extreme floods that occurred prior to, or in absence of, systematic observation. Extensive paleoflood research has been carried out in Arizona, and paleoflood data from rivers throughout the state has been combined to establish a regional paleoflood chronology that extends 5000 years (Ely 1992; Ely et al. 1993). This wealth of paleohydrological data provides a unique opportunity to evaluate the 1993 events in the context of the Holocene history of flooding in central Arizona.

Much of the Arizona paleoflood data has been obtained using the slackwater depositpaleostage indicator (SWD-PSI) method (Baker 1987, 1989). This approach involves relating geological evidence for extreme flooding in bedrock canyons to discharge-dependent water surface profiles calculated from a fixed boundary hydraulic model (O'Connor and Webb, 1988). The primary types of geologic evidence for flooding are flood slackwater deposits (SWD) -deposits of sand and silt that accumulate in areas of markedly reduced flow velocities during large floods. In many bedrock canyons, deposits from the largest floods are often found in areas protected from low and moderate flood events where they can persist from 100s to $1000 \mathrm{~s}$ of years, particularly in arid and semi-arid climates. Age estimates can be obtained for individual 


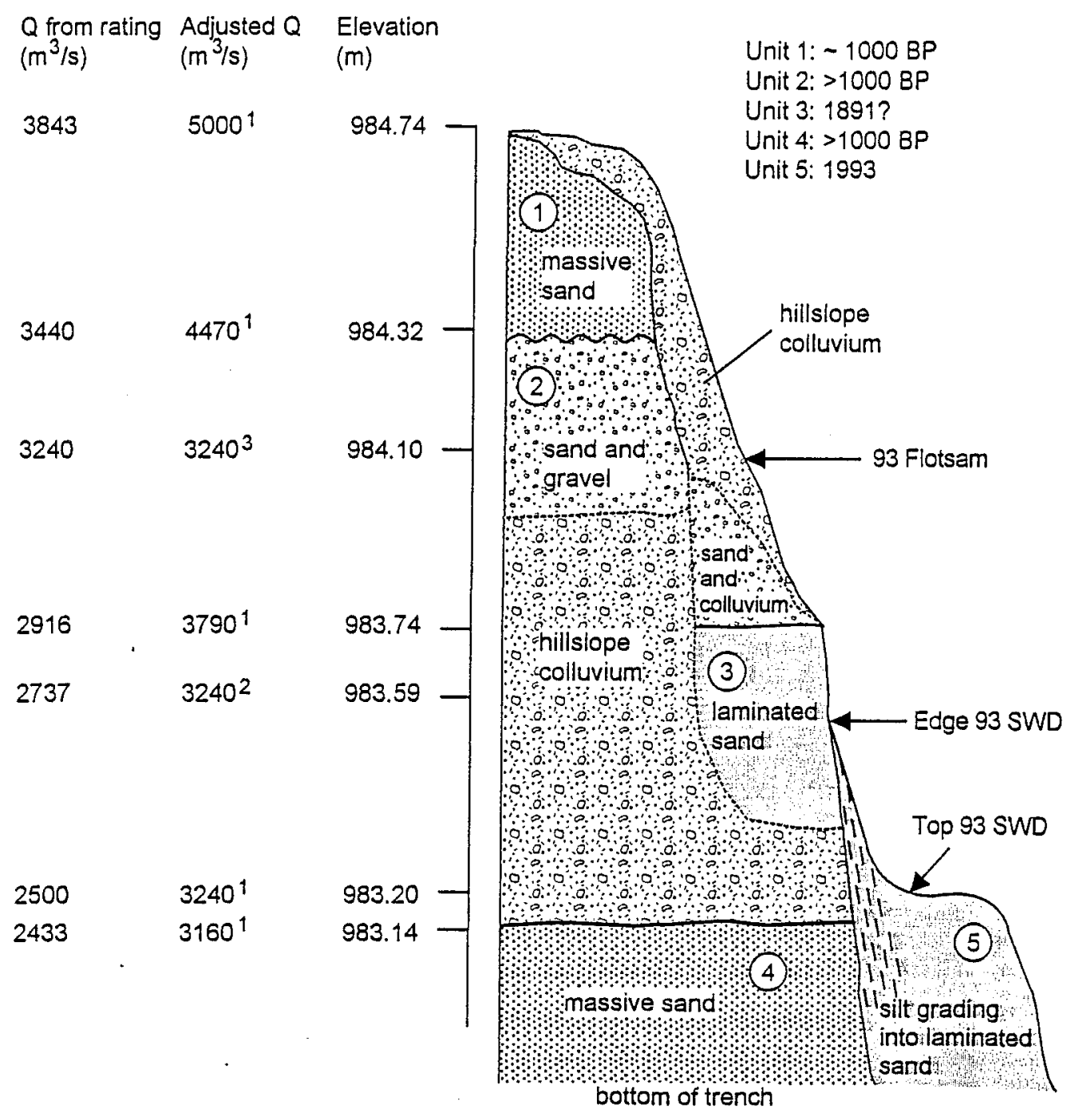
1. $35 \%$ adjustment based on average difference between the top of massive slackwater
deposit and flotsam emplaced by the 1993 flood at this site.

2. $7 \%$ adjustment based on average difference between the tapering edge of a massive slackwater deposit and the flotsam emplaced by the same flood.

3. No adjustment - definitive highwater mark.

Figure 14. Schematic depiction of slackwater deposit stratigraphy at the paleoflood site discussed in the text. Discharges shown at left are from step-backwater modeling of a $500 \mathrm{~m}$ reach of the river. Adjusted discharges reflect correction for differences in flood stage inferred from different types of highwater marks (flotsam vs. slackwater deposits) from the largest 1993 flood at this site. Several tributaries that enter the river between this site and the gage below Tangle Creek experienced significant flooding in the winter of 1993. 
deposits using ${ }^{14} \mathrm{C}$ dating of organic material within or between them, or with age constraints based on the presence of diagnostic archeological artifacts. The presence of multiple deposits in a stratigraphic sequence allows for a relative age relationship between deposits to be determined. Paleoflood stages inferred from SWDs can be reinforced or augmented with other types of paleostage indicators (PSIs) including relict high-water marks such as flotsam lines, flood scoured hillslopes, flood damaged vegetation, etc.

SWD-PSI paleoflood studies are only suited to bedrock canyons because stable boundary conditions are assumed in the modeling, and only in such environments can flood deposits persist for long periods of time and best retain their original relationship to the stream channel. On the Verde River, the relation between slackwater deposits from the 1993 floods and the stratigraphy of older flood slackwater deposits has been investigated in such a canyon setting.

\section{Paleohydrological context of the 1993 floods in the Verde Basin}

SWD-PSI paleoflood studies on two reaches of the Verde River between the Camp Verde and Tangle Creek gage sites have produced a detailed, well-constrained paleoflood chronology that spans more than 1000 years (Ely and Baker 1985, O'Connor et al. 1986). Post-1993 flood investigations of the SWD stratigraphy at selected sites in these reaches have provided valuable information regarding the relative magnitude of the 1993 event in the context of this long record of flooding. The stratigraphic column shown in Figure 14 is a schematic depiction of a trench in a flood deposit examined in June, 1993. The trench site was found in an isolated alcove well protected from low and moderate magnitude floods along the river. This new site supplements a previous paleoflood study of this reach by O'Connor et al. (1986). Our interpretation of the stratigraphy incorporates evidence specific to this site combined with inferences derived from well-described flood stratigraphy from the paleoflood site downstream (Ely and Baker, 1985). Age designations shown in the figure are taken from those determined for deposits at the downstream reach that we believe are correlative. Our belief is supported by examination of the downstream sites following the floods, and the observation of similar relative relationships between individual flood deposits and their associated flood magnitude estimates.

The uppermost deposit in the section is correlative to the uppermost deposit at the downstream site where its maximum age has been constrained to $1000 \mathrm{yr}$. BP based on diagnostic archeological artifacts found on the surface and a radiometric date of in situ charcoal (Ely and 


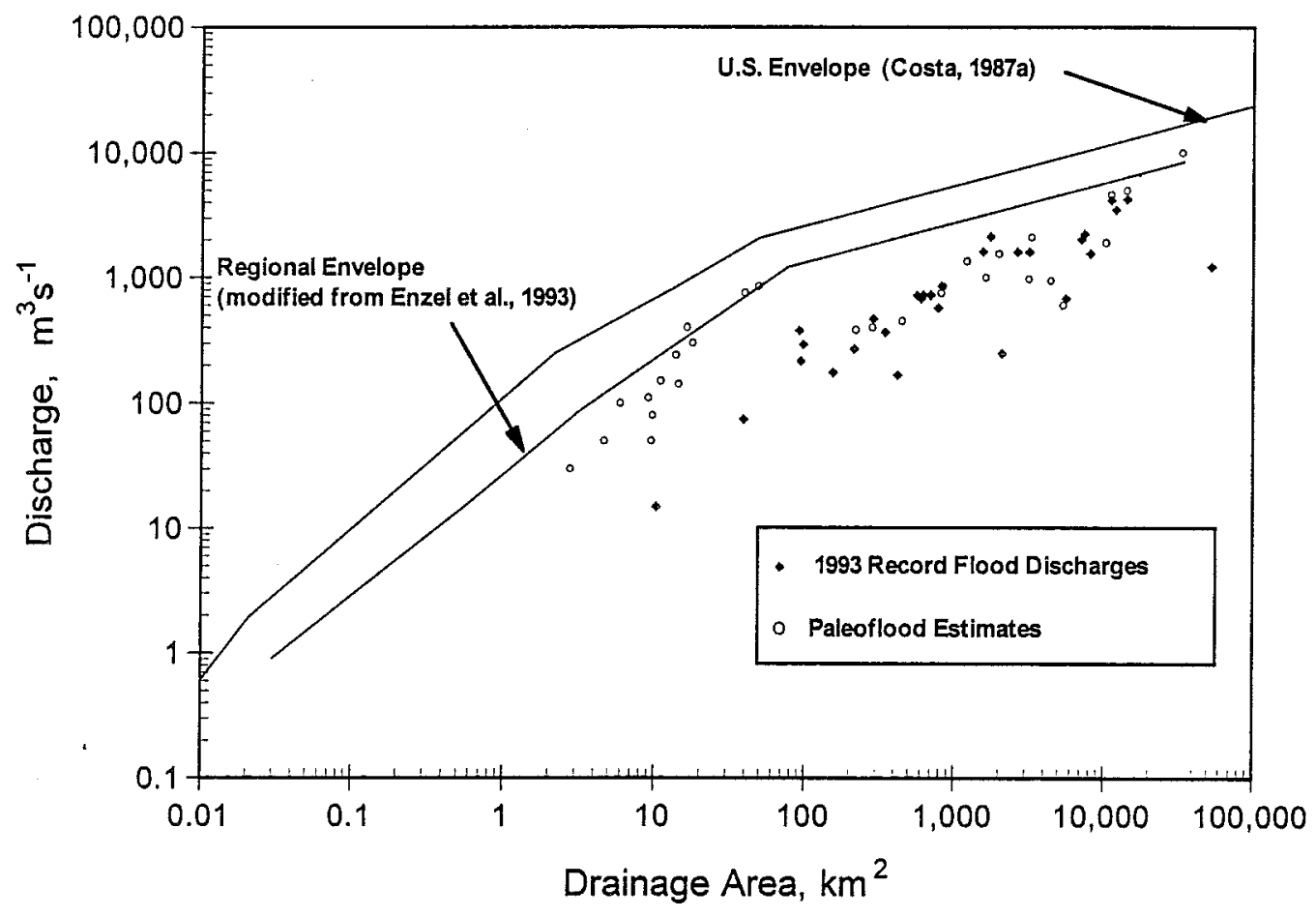

Figure 15. Comparison of the 1993 record flood peaks from unregulated basins to paleofloods and the envelope curve of the maximum gaged and historical floods in Arizona. Envelope curve slightly modified from Enzel et al. (1993). 
Baker, 1985). The underlying unit (unit 2) predates unit 1 by some unknown amount. Unit 2 is separated from unit 4 by a layer of hillslope colluvium, suggesting a relatively long hiatus in flood deposition; but the lack of any absolute age control precludes any age designation more specific than that it is older than unit 1 . Unit 3 is interpreted as a deposit inset into the colluvial unit separating units 2 and 4. Based on similarities in stratigraphic relationships and discharge estimates from the downstream site this unit is inferred to be from the 1891 flood. Unit 5 is the deposit from the largest of the 1993 floods at this site (probably February 20, 1993). Its stratigraphic relationship to the rest of the sequence is obvious. We note that the dramatic increase in discharge of the early January flood between Camp Verde and Tangle Creek was such that the peak discharge was less than that of the late February flood at this site. However, at sites downstream, the early January flood was the largest.

At this site, there is evidence for five large floods. Three are larger than the 1993 flood, two of the three occurred prior to $1000 \mathrm{yr}$. BP, and one occurred slightly more than a century ago (in 1891). The two oldest floods were considerably larger than the 1993 event, whereas the 1993 event and the 1891 event were similar in magnitude. The magnitude of the 1891 flood in the vicinity of the Tangle Creek gage is estimated to be only slightly larger than the 1993 event. This is consistent with our stratigraphic interpretation and that of Ely and Baker (1985). There is also evidence at this site for a flood that was slightly smaller than the 1993 flood that must have occurred prior to $1000 \mathrm{yr}$. BP (unit 4).

\section{Regional Peak Flood Magnitude Characteristics}

Combining the regional paleoflood data with all gaged and historical flood discharge data from Arizona illustrates an interesting relationship in regional flood magnitude-drainage area relationships. The plot shown in Figure 15 depicts the largest gaged, historical and paleoflood discharges for drainage basins of varying area in the Lower Colorado River basin (see Enzel et al. 1992). An envelope curve delimits the maximum values of the data spread. The position of the curve is based only on the gaged and historical flood data, however. The addition of the paleoflood values on the graph effectively extends the temporal base of the data set in real time by $100 \mathrm{~s}$ to $1000 \mathrm{~s}$ of years in some cases. Because all of the paleoflood values fall on or very near the curve, it has been proposed as a reasonable approximation of a natural upper bound on flood magnitudes in this region that has persisted for the last several thousand years (Enzel et al. 1992). 
Comparing the 1993 record flood peaks to this figure provides an interesting perspective on the relative magnitude of this major winter flooding episode. From this comparison, it is clear that many individual flood peaks in 1993 were quite large, but all were within the realm of documented natural tendencies of extreme floods in the region, as the Verde River paleoflood data attest. Some flood peaks from the larger basins were relatively close to the envelope, whereas record floods in basins less than about $1000 \mathrm{~km}^{2}$ were small in relation to the curve. This is because extreme floods in small basins within the region usually result from localized, intense thunderstorms. The plot also indicates that basins without paleoflood records experienced floods comparable to and, in some cases, larger than, the largest paleofloods recorded in basins of similar sizes.

\section{DISCUSSION}

Figure 15 encapsulates the immense regional scale of the 1993 flooding as expressed in the number of record peaks in unregulated basins. Considering the regional scale and the magnitude of individual events in the largest basins, we contend that the anomalous hydroclimatological conditions which characterized the 1993 flood episodes are probably analogous to those associated with most of the paleofloods in the largest basins. The sequence of events culminating in the 1993 flood episode illustrates that certain hydroclimatological phenomena are extremely conducive to the generation of huge floods on large rivers in Arizona -- the Salt and Verde, for example. These phenomena include: abnormally high rainfall totals throughout the region, repeated accumulation and melting of heavy snowpack, direct rainfall on snowpack, and prolonged periods of relatively moderate intensity rainfall over large areas and of high intensity rainfall over smaller areas. Each of these processes in 1993 was initiated and perpetuated by a persistent, anomalous circulation pattern that repeatedly steered alternately warm and cold storms into the region along a southerly displaced storm track over a three-month period. The scale of these phenomena was such that streams throughout much of the state experienced severe flooding.

Evidence for larger floods in the paleoflood record is thus suggestive of more extreme variations on the hydroclimatic scenario played out in 1993. Furthermore, optimal basin-wide timing of flood runoff coming from a similar set of circumstances might also produce events large enough to have emplaced the paleoflood deposits. Recall that a larger peak on the Verde may 
have occurred in 1993 if relatively slight variations in the timing of precipitation had been different in disparate portions of the basin.

In a summary treatment of paleoflood chronologies from the southwestern United States, Ely (1992) and Ely et al. (1993) proposed that there is an indication of temporal clustering of large floods that is consistent with evidence of hydrological variability inferred from other types of proxy indicators of regional climate change over the last 5000 years. The periods of apparent clustering defined by Ely et al. (1993) were determined by stratigraphic evidence (SWDs) of approximately synchronous regional flooding. Their analysis suggested that the timing of clusters of large floods correspond to periods of transitions in the regional climate. The interpretation of the 1993 floods in the context of regional hydroclimatological phenomena stemming from global circulation characteristics offers important insights into the physical basis of flood clustering in the paleorecord in the southwest. The 1993 flood scenario provides a convincing modern analogue for the processes that must have operated to generate comparably large paleofloods. Hence we suggest that clusters of flooding in the paleorecord of the Southwest are best explained by a global circulation scenario involving an unusually high frequency of winters characterized by a southerly displaced Pacific storm track enhanced by subtropical flow. The key factor in this scenario is the development of a circulation anomaly in the eastern North Pacific Ocean which promotes the formation of a split flow in the westerlies and forces the southern branch of the normal Pacific storm track to lower latitudes. Such a winter pattern has been associated with ENSO conditions over the last 100+ years (e.g., in the winters of 1890/91, 1964/65, 1979/80, 1992/93, 1993/94) but might also develop independent of an El Niño in response to other kinds of global circulation changes.

\section{CONCLUDING REMARKS}

In presenting our discussion of the 1993 floods in their hydroclimatological and geological contexts, we have shown that the flood episode was comparable in terms of regional scale and individual flood magnitudes to the largest known flooding episodes in this region over at least the last 1000 years, and possibly as long as the last 5000 years. The 1993 episode resulted from a distinctive combination of hydroclimatological and hydrological events. During the middle and late Holocene, such events have characterized periods of climatic transition, both regionally and globally. Taken in the context of the paleoflood record and its connection to regional hydroclimatological phenomena, characteristics of the 1993 flood episode are remarkably 
consistent with documented regional trends in the temporal variability of extreme flooding in the Southwest.

We believe that it is important that the circumstances (local, regional, and global scale) leading to the floods be taken seriously as examples of what physical processes are required to generate such large, voluminous floods in large drainage basins in Arizona. The wealth of data pertaining to the circumstances of the floods is of great value in this regard. Not only has it provided new, more detailed perspectives on the likely causes of the largest floods in the paleoflood record, but it can also serve as a tool for flood hydrologists, water supply managers, and floodplain managers to better understand the physical processes associated with extreme floods and their inherent patterns. An enhanced understanding could lead to better management policies, better water supply forecasting and reservoir management over both the long and short terms, and a greater ability to foresee local consequences of regional and global climatic phenomena.

\section{ACKNOWLEDGMENTS}

Many individuals helped in the preparation of this manuscript. We owe particular thanks to Chris Smith of the USGS, Tucson, for allowing repeated access to the USGS hydrological data base. Phil Pearthree of the Arizona Geological Survey and Jon Fuller of J.E. Fuller Inc. participated in the post-1993 flood investigation on the Verde River. Steve Waters of the Maricopa County Flood Control District and Dallas Reigle of the Salt River Project provided precipitation data. Michelle Wood and Fenbiao Ni of the Tree-Ring Laboratory, University of Arizona, compiled the flood hydroclimatology and atmospheric circulation data and prepared several figures. Pete Corrao of the Arizona Geological Survey also drafted several figures. This research was supported in part by the Salt River Project, the Arizona Geological Survey, the Hydrological Sciences Program of the National Science Foundation, grant EAR-9305252, the United States Geological Survey Water Resources Research Grant Program, award \# 14-08-0001-G1754, and the National Institute for Global Environmental Change - Western Regional Center, Research Agreement No. W/GEC 92-020. This manuscript is contribution \#41 of the Arizona Laboratory for Paleohydrological and Hydroclimatological Analysis (ALPHA), Department of Geosciences, University of Arizona.

\section{REFERENCES CITED}

Baker, V. R., 1989, Magnitude and frequency of paeleofloods, in Beven, K., and Carling, P., eds., Floods: hydrological, sedimentological, and geomorphological implications: New York, John Wiley, p. 171-183.

Baker, V. R., 1987, Paleoflood hydrology and extraordinary flood events: Journal of Hydrology, v. 96, p. $79-99$. 
Bell, G. D. and Basist, A. N. 1994. The global climate of December 1992-February 1993. Part I: warm ENSO conditions continue in the tropical Pacific; California drought abates: Journal of Climate, $v$ 7, p 1581-1605.

Chin, E. H., Aldridge, B. N., and Longfield, R. J., 1991, Floods of February 1980 in southern California and central Arizona: U. S. Geological Survey Professional Paper 1494, 126 p.

Ely, L.L., 1992, Large floods in the southwestern United States in relation to late Holocene climatic variations [Ph.D. thesis]: Tucson, University of Arizona, $326 \mathrm{p}$.

Ely, L. L., and Baker, V. R., 1985, Reconstructing paleoflood hydrology with slackwater deposits: Verde River, Arizona: Physical Geography, v. 6, p. 103-126.

Ely, L. L., Enzel, Y., Baker, V. R., and Cayan, D. R., 1993, A 5000-year record of extreme floods and climate change in the southwestern United States: Science, v. 262, p. 410-412.

Enzel, Y., Ely, L. L., House, P. K., Baker, V. R., and Webb, R. H., 1993, Paleoflood evidence for a natural upper bound to flood magnitudes in the Colorado River Basin: Water Resources Research, v. 29, p. 2287-2297.

Hirschboeck, K. K., 1985, Hydroclimatology of flow events in the Gila River Basin, central and southern Arizona [Ph.D. thesis]: Tucson, University of Arizona, $335 \mathrm{p}$.

Hirschboeck, K.K., 1987. Hydroclimatically-defined mixed distributions in partial duration flood series, in Singh, V.P., ed., Hydrologic Frequency Modeling, D. Reidel Publishing Company, 199-212.

Hirschboeck, K. K., 1988, Flood hydroclimatology, in Baker, V. R., Kochel, R. C., and Patton, P. C., eds., Flood Geomorphology: New York, John Wiley \& Sons, p. 27-50.

Huckleberry, G. A., 1994, Contrasting channel response to floods on the middle Gila River, Arizona: Geology, v. 22, p. 1083-1086.

O'Connor, J. E., Fuller, J. E., and Baker, V. R., 1986, Late Holocene flooding within the Salt River Basin, central Arizona: unpublished report to the Salt River Project, Tempe, AZ.

United States Army Corps of Engineers, 1994, Flood Damage Report, State of Arizona, Floods of 1993: United States Army Corps of Engineers, Los Angeles District, South Pacific Division, $107 \mathrm{p}$. 